\title{
Morfologia polínica de eudicotiledôneas arbóreas da Serra da Capoeira Grande, Maciço Geológico da Pedra Branca, Rio de Janeiro, Brasil
}

\author{
Cynthia Fernandes Pinto da Luz' ${ }^{1}$ Marcia Aguiar de Barros ${ }^{2}$ \& Ortrud Monika Barth ${ }^{2,3}$
}

\author{
'Instituto de Botânica, Núcleo de Pesquisa em Palinologia, Avenida Miguel Stefano 3.687, CEP 04301-902, São Paulo, SP, Brasil. \\ cyluz@yahoo.com.br \\ 2Universidade Federal do Rio de Janeiro, Laboratório de Palinologia, Departamento de Geologia, Centro de Ciências Matemáticas \\ e da Natureza, Avenida Athos da Silveira Ramos 274, CEP 21040-000, Rio de Janeiro, RJ, Brasil. marcabarros@yahoo.com \\ ${ }^{3}$ Instituto Oswaldo Cruz, Laboratório de Morfologia e Morfogênese Viral, Avenida Brasil 4.365, CEP 21040-900, Rio de Janeiro, RJ, Brasil. \\ monikabarth@gmail.com
}

Recebido em 30.IV.2016

Aceito em 20.XI.2018

DOI $10.21826 / 2446-8231201873308$

RESUMO - É apresentada a morfologia polínica detalhada de 37 espécies arbóreas pertencentes a 20 famílias de eudicotiledôneas ocorrentes no Maciço Geológico da Pedra Branca, na Área de Proteção Ambiental da Serra da Capoeira Grande, Rio de Janeiro. O estudo baseia-se em observações e ilustrações em microscopia fotônica. A variação das características morfológicas é ampla e significativa, podendo ser aplicada na identificação das respectivas espécies de origem.

Palavras-chave: árvores, grãos de pólen, mata atlântica

ABSTRACT - Pollen morphology of arboreal eudicotyledons of Serra da Capoeira Grande, Pedra Branca Geological Massif, Rio de Janeiro, Brazil. The pollen grain morphology of 37 tree species belonging to 20 families of eudicotyledons occurring in the Pedra Branca Mountain range, at the Environmental Protection Area (EPA) of Capoeira Grande ridge, Rio de Janeiro, is presented. This study was based on morphological observations and pollen grain illustrations using light microscopy. Pollen grain characteristics are strongly variable and may be used for identification of the respective species of origin.

Keywords: Atlantic forest, pollen grains, trees

\section{INTRODUÇÃO}

O Complexo Geológico do Maciço da Pedra Branca é constituído de rochas eruptivas e sedimentares, bastante erodidas e trabalhadas, de modo que uma variedade de tipos de solos e microambientes proporcionou a introdução de uma vegetação variada de clima tropical (Pereira 2010). Peixoto et al. (2004) relataram que a Serra da Capoeira Grande se configura como um morrote isolado do Maciço da Pedra Branca com 159m de altitude e, abriga remanescente da Floresta Atlântica de baixada, incluindo uma população nativa de pau-brasil (Caesalpinia echinata Lam), além de famílias arbóreas representadas por 58 gêneros e 69 espécies. Em 2010 foi criada a Área de Proteção Ambiental Estadual da Serra da Capoeira Grande (APA da Serra da Capoeira Grande) para proteger o patrimônio ambiental da região, recuperar e preservar o ecossistema local, propiciar estudo científico da flora e da fauna da região e promover o lazer, quando este for compatível com os demais objetivos da APA (Projeto de Lei No 3212/2010). Já no Maciço da Pedra Branca, dentro dos limites do Parque Estadual da Pedra Branca, em área de antigas carvoarias situadas em meia encosta voltada para sudoeste e circunscritas à bacia do rio Caçambe, tributário de primeira ordem do rio Camorim, foram registradas 120 espécies de árvores distribuídas em 95 gêneros e 38 famílias (Santos et al. 2006). Dentre as árvores e arbustos da porção meridional do Maciço da Pedra Branca foram identificadas 324 espécies pertencentes a 154 gêneros e 52 famílias (Freire 2010). Muitas espécies que ocorrem dentro dos limites do Parque Estadual da Pedra Branca também são encontradas na Serra da Capoeira Grande. As famílias que apresentaram maiores valores de importância (VI) na APA da Capoeira Grande foram Solanaceae (com 34,1\% do VI), Leguminosae (Mimosoideae com 16,4\%, Papilionoideae com $7,9 \%$ e Caesalpinioideae com $2,1 \%$ ), Nyctaginaceae (13\%), Anacardiaceae $(6,5 \%)$ e Flacourtiaceae $(6,1 \%)$. As espécies com maior número de indivíduos na área também apresentaram maior VI: Metternichia princeps Mik. (com 40,4\% dos indivíduos e 33,7\% do VI), Pseudopiptadenia contorta (DC.) G.P. Lewis \& M.P. Lima (9,3 e 12,6\%), Guapira hirsuta (Choisy) Lundell (7,5 e 7,8\%), Astronium 
fraxinifolium Schott ex Spreng. (5,6 e 5,7\%). Caesalpinia echinata Lam. apresentou 2,4\% dos indivíduos amostrados e 2,1\% do VI (Peixoto et al. 2005).

A história de proteção das florestas do Maciço da Pedra Branca sempre esteve associada à preservação do potencial hídrico da região, impulsionando o governo federal em 1908 a adquirir as áreas dos mananciais do rio Grande e do rio Camorim, visando o aprimoramento dos sistemas de captação e distribuição de água potável. Aspectos geológicos, geomorfológicos, florísticos e faunísticos de grande valor científico, histórico, estético e recreativo, tornam a região do Maciço da Pedra Branca, inserida no complexo da Mata Atlântica, um local com grande potencial turístico. Entretanto, em função da sua localização, a área se encontra em região metropolitana densamente povoada, alvo de pressões imobiliárias, além de atividades ilegais de caça e plantio, que conflitam com os propósitos de preservação ambiental do remanescente florestal (Magalhães-Corrêa 1933, Oliveira 2005, Solórzano 2006).

O presente estudo tem como objetivo a caracterização morfopolínica de espécies arbóreas de famílias ocorrentes na APA da Serra da Capoeira Grande, no Complexo Geológico da Pedra Branca, Rio de Janeiro, servindo como material de referência para estudos em Palinologia que possam ser aplicados na conservação ambiental. $\mathrm{O}$ conhecimento resultante auxilia no reconhecimento de táxons botânicos durante a análise de sedimentos contendo grãos de pólen, como no caso de pesquisas em Palinologia do Quaternário e em Melissopalinologia. Em decorrência é possível identificar os respectivos tipos de vegetação ao nível local ou regional e sua dinâmica espacial e temporal, assim como as preferências tróficas dos polinizadores.

\section{MATERIAL E MÉTODOS}

As 37 espécies analisadas foram selecionadas do levantamento fitossociológico do componente arbóreo da Floresta Atlântica de um trecho da Serra da Capoeira Grande segundo Peixoto et al. (2004), cujos nomes das espécies foram apresentados sensu Cronquist (1988), atualizados no item resultados do presente trabalho segundo APG III (2009), quando preciso. A validação dos nomes das espécies foi feita utilizando a base de dados fornecida pela Flora do Brasil 2020 (2018). A área de estudo está localizada no bairro de Pedra de Guaratiba, zona oeste do município do Rio de Janeiro (22 $54^{\prime} 10^{\prime \prime}$ 'S e $\left.43^{\circ} 12^{\prime} 27^{\prime \prime} W\right)$ (Fig. 1). A região caracteriza-se por apresentar temperatura do ar média anual de $23,6^{\circ} \mathrm{C}$, sendo o mês de fevereiro o mais quente, com temperatura média de $26,7^{\circ} \mathrm{C}$ e junho, o mais frio, com média de $21,0^{\circ} \mathrm{C}$. O total médio anual de precipitação é de 1.027,2 mm. De acordo com o sistema de Köppen, o clima da região é do tipo Aw - Clima Tropical Chuvoso. As chuvas são abundantes no verão e escassas no inverno, porém sem mês seco durante o ano (Peixoto et al. 2004).

O material estudado foi coletado no Herbário do Jardim Botânico do Rio de Janeiro (RB) e no Herbário Científico do Estado de São Paulo "Maria Eneyda P. Kauffmann Fidalgo" do Instituto de Botânica (SP). Procurou-se retirar

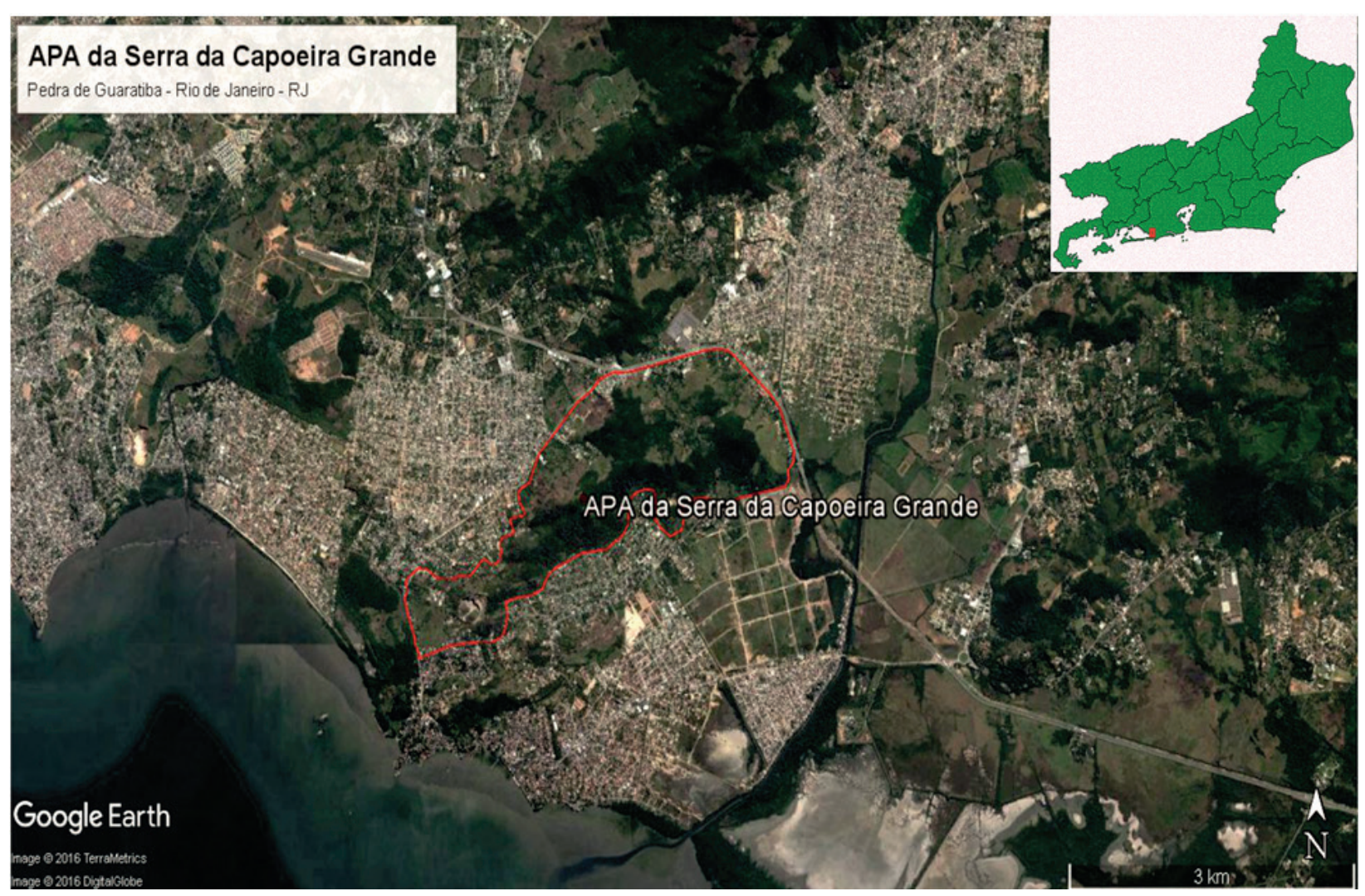

Fig. 1. Localização da área de estudo na APA da Serra da Capoeira Grande, Rio de Janeiro, Brasil (modificado de Google Maps). 
material polínico das exsicatas mencionadas na listagem de Peixoto et al. (2004), porém a maioria encontrava-se sem botões florais, flor ou em fruto, e por isso, realizouse a coleta de material fora da área de estudo, dando-se preferência ao proveniente do Rio de Janeiro.

As lâminas de microscopia com o material polínico encontram-se depositadas na Palinoteca do Núcleo de Pesquisa em Palinologia, no Instituto de Botânica, São Paulo, Brasil.

O método padrão utilizado para a preparação dos grãos de pólen das espécies arbóreas da Pedra Branca foi o da acetólise clássica de Erdtman (1960). Após a preparação das lâminas de microscopia, os grãos de pólen foram medidos dentro do prazo máximo de sete dias. Este prazo foi aplicado para evitar possíveis problemas de alterações no tamanho dos grãos de pólen (Melhem \& Matos 1972, Salgado-Labouriau 1973).

As medidas dos eixos foram realizadas em 25 grãos de pólen tomados ao acaso, usando-se o tambor micrométrico
Olympus OSM acoplado à ocular do microscópio Olympus BX 50, distribuídos em pelo menos três lâminas, visando-se uma uniformidade da amostra (Salgado-Labouriau et al. 1965). As medidas das aberturas e da espessura da exina foram feitas em 10 grãos de pólen. Para as 25 medidas de cada espécime foram calculadas a média aritmética (x), o desvio padrão da média $\left(\mathrm{s}_{\mathrm{x}}\right)$, o desvio padrão da amostra (s), o coeficiente de variabilidade (CV\%), o intervalo de confiança a 95\% (IC95\%) e a faixa de variação (FV). Nos casos em que foram feitas apenas dez medidas foi calculada a média aritmética $(\mathrm{x})$.

A terminologia adotada para as descrições polínicas foi a de Barth \& Melhem (1988), atualizando-a, quando necessário, com a apresentada por Punt et al. (2007).

Os grãos de pólen acetolisados e preparados para observação em microscopia fotônica foram fotografados digitalmente em um fotomicroscópio Olympus acoplado a uma câmera de vídeo e um microcomputador, utilizando-se o programa Image Pro-plus para Windows 3.1.

\section{RESULTADOS}

\section{Chave da morfologia dos grãos de pólen das famílias estudadas na APA da Serra da Capoeira Grande, Complexo Geológico do Maciço da Pedra Branca (Rio de Janeiro, Brasil)}

Grãos de pólen de tamanho pequeno $(<16,0 \mu \mathrm{m})$, sexina espiculada. Ocotea divaricata (Lauraceae)

Porados

Grãos de pólen de tamanho pequeno, oblato-esferoidais à prolato-esferoidais, 2(-3)4-5 zono-porados, poros com áspide e opérculo, sexina granulada Sorocea bonplandii (Moraceae)

Tricolpados

1a. Grãos de pólen de tamanho médio, colpos longos .

2a. prolatos, colpos mais largos em suas porções subequatoriais e constrictos no equador, sexina escabrada, raríssimos grãos de pólen sincolpados Jacaranda micrantha (Bignoniaceae) 2b. subprolatos, colpos muito largos nas porções subequatoriais e sem constrição no equador, sexina reticulada homobrocada, raríssimos grãos de pólen sincolpados Tabebuia impetiginosa (Bignoniaceae) 2c. prolatos, colpos estreitos com extremidades afiladas, com margem estreita, levemente constrictos no equador, sexina reticulada, homobrocada, raríssimos grãos de pólen 3-zono-colporados Cariniana ianeirensis (Lecythidaceae) 2 d. oblato esferoidais à prolato esferoidais, colpos estreitos com extremidades arredondadas e elementos isolados da sexina, sexina espiculada-granulada Guapira hirsuta (Nyctaginaceae) Guapira opposita (Nyctaginaceae)

2e. subprolatos, colpos estreitos com extremidades arredondadas e elementos isolados da sexina, sexina granulada Seguieria floribunda (Phytolacaceae)

1b. Grãos de pólen de tamanho médio, colpos curtos

3a. oblato esferoidais, colpos retangulares, sexina espiculada ....

3b. oblato esferoidais, colpos largos com extremidades arredondadas, sexina reticulada

Coutarea hexandra (Rubiaceae) Psychotria carthagenensis (Rubiaceae)

Tetracolpados

Grãos de pólen de tamanho médio, prolato-esferoidais, raríssimas vezes 3-5 colpados, colpos curtos e estreitos, com margem, sexina rugulada Myrsine umbellata (Myrsinaceae)

\section{Pantocolpados}

Grãos de pólen de tamanho médio, esferoidais, colpos que se anastomosam delimitando áreas arredondadas e bem definidas da sexina, sexina reticulada, heterobrocada. Sparattosperma leucanthum (Bignoniaceae) 
Tetracolporados

Grãos de pólen de tamanho grande, prolato-esferoidais, raríssimas vezes 5 colporados, colpos muito curtos e estreitos, com margem estreita, endoabertura lolongada, de difícil visualização, não excedendo a margem dos colpos, sexina reticulada com muros com espículos Chorisia speciosa (Bombacaceae)

\section{Sincolporados}

1a. Grãos de pólen de tamanho pequeno à médio, oblatos à suboblatos, cólporos estreitos, conservando sempre a mesma largura, endoabertura lalongada com extremidades afiladas, com amplo ou pequeno fastígio, sexina escabrada ......

Campomanesia eugenioides (Myrtaceae)

Eugenia maroviana (Myrtaceae)

1b. Grãos de pólen de tamanho pequeno, oblatos, cólporos estreitos que se alargam na área polar, endoabertura lalongada com extremidades afiladas, com amplo fastígio, sexina escabrada Syzygium cumini (Myrtaceae)

\section{Tricolporados}

1a. Grãos de pólen de tamanho pequeno, subprolatos a prolato-esferoidais, cólporos longos e estreitos, com constrição mediana e com margem estreita, endoabertura lalongada, com leve constrição mediana e extremidades alargadas, exina com 1,85-2,80 $\mu \mathrm{m}$, sexina microrreticulada Maytenus communis (Celastraceae) Maytenus robusta (Celastraceae) 1b. Grãos de pólen de tamanho pequeno, subprolatos, cólporos longos e estreitos, sem constrição mediana e com margem estreita, endoabertura circular, exina com 1,40-2,05 $\mu \mathrm{m}$, sexina microrreticulada

Sebastiania multiramea (Euphorbiaceae) Sebastiania serrata (Euphorbiaceae)

2a. Grãos de pólen de tamanho pequeno, subprolatos, cólporos longos e estreitos, sem constrição mediana e com extremidades afiladas, sexina microrreticulada, muito mais espessado que a nexina

3a. cólporos sem margem, operculados, endoabertura lalongada e retangular, exina com 1,10-1,25 $\mu \mathrm{m}$

Machaerium aculeatum (Leguminosae/Papilionoideae)

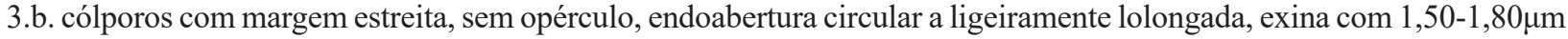
Pterocarpus rohrii (Leguminosae/Papilionoideae)

2b. Grãos de pólen de tamanho pequeno, oblato esferoidais, cólporos curtos e estreitos com extremidades afiladas e margem estreita, endoabertura lalongada e retangular, exina com $0,90-1,00 \mu \mathrm{m}$, sexina granulada, um pouco mais espessa do que a nexina . Ouratea stipulata (Ochnaceae) 4a. Grãos de pólen de tamanho pequeno a médio, cólporos longos e estreitos com extremidades afiladas, endoabertura lalongada, sexina microrreticulada

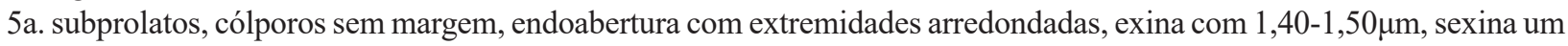
pouco mais espessa do que a nexina ...................................................................... Margaritaria nobilis (Euphorbiaceae)

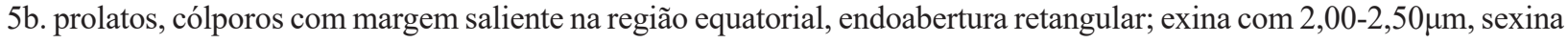
muito mais espessa do que a nexina ..................................................... Swartzia myrtifolia (Leguminosae/Papilionoideae) 4b. Grãos de pólen de tamanho pequeno a médio subprolatos, cólporos longos e estreitos, endoabertura lalongada com extremidades afiladas, exina com 1,33-1,75 $\mu \mathrm{m}$, sexina psilada, com o dobro da espessura da nexina

Casearia sylvestris (Flacourtiaceae) 6a. Grãos de pólen de tamanho pequeno a médio, oblatos, cólporos longos e estreitos, endoabertura lalongada com extremidades afiladas, exina com 0,95-1,25 $\mu \mathrm{m}$, sexina finamente reticulada-estriada, mais espessa do que a nexina

Spondias lutea (Anacardiaceae) 6b. Grãos de pólen de tamanho pequeno a médio, prolatos, cólporos longos e estreitos com extremidades afiladas, endoabertura lalongada, com extremidades afiladas, exina com 1,15-1,25 $\mu \mathrm{m}$, sexina microrreticulada, ligeiramente estriada, com o dobro da espessura da nexina Pilocarpus spicatus (Rutaceae) 7a. Grãos de pólen de tamanho médio, sub-oblatos, oblatos, oblato-esferoidais ou esferoidais, cólporos longos e estreitos, com margem estreita, endoabertura lalongada com extremidades afiladas, exina com 1,25-2,30 $\mu \mathrm{m}$, sexina mais espessa do que a nexina

8a. sexina reticulada no apocolpo e reticulada-estriada nos mesocolpos Astronium fraxinifolium (Anacardiaceae)

8b. sexina reticulada Erythroxylum pulchrum (Erythroxylaceae) 7b. Grãos de pólen de tamanho médio, oblato-esferoidais, raros 4 colporados, cólporos curtos e largos, sem margem, endoabertura lalongada, mais comprida e mais larga que o colpo com extremidades afiladas e com fastígio proeminente, exina com 2,10-3,00 $\mu \mathrm{m}$, sexina granulada, muito mais espessa do que a nexina Peschiera laeta (Apocynaceae) 9a. Grãos de pólen de tamanho médio, prolato-esferodais, cólporos longos e estreitos, com margem estreita, endoabertura lalongada com extremidades arredondadas 
10a. cólporos com membrana apertural, exina com $0,85-1,40 \mu \mathrm{m}$, sexina microrreticulada, um pouco mais espessa do que a nexina Capparis flexuosa (Capparaceae)

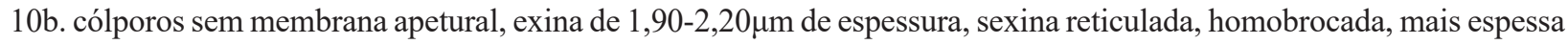
do que a nexina, raríssimos grãos de pólen sincolpados Erythroxylum cuspidifolium (Erythroxylaceae) 9b. Grãos de pólen de tamanho médio, prolatos, cólporos longos e estreitos, sem margem, endoabertura lalongada com extremidades afiladas, exina com 2,92-3,33 $\mu \mathrm{m}$, sexina reticulada, com o dobro da espessura da nexina

Casearia comersoniana (Flacourtiaceae)

11a. Grãos de pólen de tamanho médio a grande, suboblatos, cólporos curtos e estreitos, com margem microrreticulada

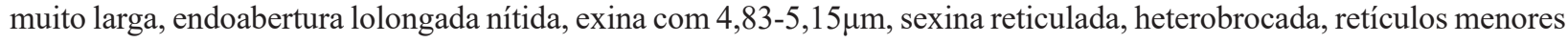
nos pólos, sexina um pouco mais espessa do que a nexina ..... Caesalpinia echinata (Leguminosae/Caesalpinioideae) 11b. Grãos de pólen de tamanho grande, endoabertura lolongada, de difícil visualização, não excedendo a margem dos colpos

12a. prolato-esferoidais, cólporos curtos e estreitos, com margem psilada seguida de estreita faixa microrreticulada, exina

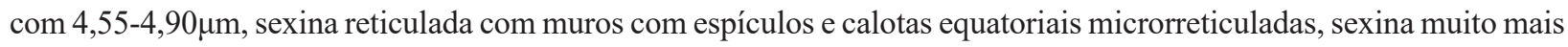
espessa do que a nexina Bombacopsis glabra (Bombacaceae)

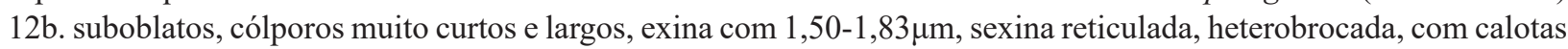
equatoriais microrreticuladas, sexina com o dobro de espessura da nexina, mais espessa na região apertural ......

Pseudobombax grandiflorum (Bombacaceae)

\section{Descrições morfológicas}

São apresentadas as descrições morfológicas polínicas de 37 espécies arbóreas pertencentes a 20 famílias de eudicotiledôneas, assim como as ilustrações dos grãos de pólen. As espécies são apresentadas por ordem alfabética das respectivas famílias mantendo-se uma sequência na citação das características morfológicas. As dimensões dos grãos de pólen e de suas estruturas são apresentadas em três tabelas na mesma sequência (Tabelas 1-3).

Anacardiaceae

Astronium fraxinifolium Schott ex Spreng (Pr. 1, Figs. 2 - 5)

Grãos de pólen de tamanho médio, isopolares, esferoidais, âmbito subtriangular; 3-zono-colporados, cólporos longos e estreitos, com margem estreita, endoabertura lalongada, com extremidades afiladas; exina de 1,40-2,30 $\mu \mathrm{m}$ de espessura, sexina reticulada no apocolpo e reticulada-estriada nos mesocolpos, muito mais espessa do que a nexina.

Material examinado: BRASIL, MINAS GERAIS, Ituiutaba, 6-VIII-1944, H. Macedo 439 (SP51983).

\section{Spondias lutea L. (nome válido Spondias mombin L.)}

$$
\text { (Pr.1, Figs. } 6 \text { - 8) }
$$

Grãos de pólen de tamanho pequeno a médio, isopolares, oblatos, âmbito circular; 3-zono-colporados, cólporos longos e estreitos, com extremidades afiladas, endoabertura lalongada, com extremidades afiladas; exina de $0,95-1,25 \mu \mathrm{m}$ de espessura, sexina finamente reticuladaestriada, mais espessa do que a nexina.

Material examinado: BRASIL, AMAZONAS, Parque Nacional do Jaú, 23.XI.1995, J.R. Pirani $s / n^{\circ}$ (SP304214).
Apocynaceae

Peschiera laeta (Mart.) Miers (nome válido Tabernaemontana laeta Mart.)

$$
\text { (Pr. 1, Figs. } 9 \text { - 13) }
$$

Grãos de pólen de tamanho médio, isopolares, oblatoesferoidais, âmbito circular; 3(-4)-zono-colporados, cólporos curtos e largos, sem margem, endoabertura lalongada, mais comprida e mais larga que o colpo, com extremidades afiladas e com fastígio proeminente; exina de 2,10-3,00 $\mu \mathrm{m}$ de espessura, sexina granulada, muito mais espessa do que a nexina.

Material examinado: BRASIL, RIO DE JANEIRO, Sepetiba, 13.IX.1963, Miguel 42 (RB119641).

\section{Bignoniaceae \\ Jacaranda micrantha Cham.}

$$
\text { (Pr. 1, Figs. } 14 \text { - 16) }
$$

Grãos de pólen de tamanho médio a grande, isopolares, prolatos, âmbito subcircular; 3-zono-colpados, colpos longos e relativamente estreitos, constritos no equador, e mais largos em suas porções subequatoriais; alguns grãos

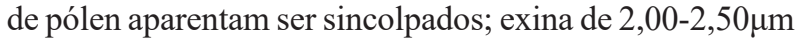
de espessura, sexina escabrada, um pouco mais espessa do que a nexina.

Material examinado: BRASIL, SÃO PAULO, Mogi das Cruzes, 17.II.1950, M. Kuhlmann 2363 (SP65157).

\section{Sparattosperma leucanthum (Vell.) K. Schum}

$$
\text { (Pr. 2, Figs. } 17 \text { - 19) }
$$

Grãos de pólen de tamanho médio, apolares, esferoidais; clipeado, colpos que se anastomosam delimitando áreas 
Tabela 1. Medidas ( $\mu \mathrm{m})$ em vista equatorial dos grãos de pólen isopolares de espécies arbóreas da APA da Serra da Capoeira Grande, Maciço da Pedra Branca, Rio de Janeiro ( $\mathrm{n}=25)$. $x$ - média aritmética; $\mathrm{s} x$ - desvio padrão da média; s- desvio padrão da amostra; CV\%- coeficiente de variabilidade; IC95\%- intervalo de confiança a 95\%; P/E- relação entre o eixo polar e o eixo equatorial.

\begin{tabular}{|c|c|c|c|c|c|c|c|c|c|c|c|}
\hline \multirow[t]{2}{*}{ Espécies } & \multicolumn{5}{|c|}{ Eixo Polar } & \multicolumn{5}{|c|}{ Eixo Equatorial } & \multirow[t]{2}{*}{$\mathrm{P} / \mathrm{E}$} \\
\hline & $x$ & $\mathrm{~s} \underline{x}$ & $\mathrm{~s}$ & $\mathrm{CV} \%$ & $\mathrm{IC} 95 \%$ & $x$ & $\mathrm{~S} \underline{x}$ & $\mathrm{~s}$ & $\mathrm{CV} \%$ & $\mathrm{IC} 95 \%$ & \\
\hline Astronium fraxinifolium & 27,2 & 0,2 & 1,1 & 4,2 & $26,7-27,6$ & 27,2 & 0,2 & 0,9 & 3,3 & $26,8-27,6$ & 1,00 \\
\hline Spondias lutea & 23,5 & 0,6 & 2,8 & 12,1 & $22,3-24,6$ & 34,1 & 0,6 & 3,0 & 8,8 & $32,8-35,3$ & 0,69 \\
\hline Peschiera laeta & 36,8 & 0,3 & 1,7 & 4,5 & $36,1-37,5$ & 36,2 & 0,2 & 2,8 & 7,8 & $35,4-36,9$ & 1,00 \\
\hline Jacaranda micrantha & 51,6 & 0,7 & 3,3 & 6,3 & $50,2-52,9$ & 35,3 & 0,6 & 3,1 & 8,7 & $34,0-36,6$ & 1,46 \\
\hline Tabebuia impetiginosa & 39,4 & 0,6 & 2,8 & 7,1 & $38,3-40,6$ & 29,5 & 0,4 & 2,1 & 7,1 & $28,6-30,3$ & 1,33 \\
\hline Bombacopsis glabra & 67,2 & 0,9 & 4,4 & 6,5 & $65,4-69,0$ & 65,2 & 0,2 & 3,8 & 5,8 & $64,5-65,9$ & 1,03 \\
\hline Chorisia speciosa & 65,1 & 0,7 & 3,4 & 5,3 & $63,6-66,5$ & 59,0 & 0,2 & 3,8 & 6,4 & $58,3-59,6$ & 1,10 \\
\hline Pseudobombax grandiflorum & 63,7 & 0,4 & 5,7 & 9,0 & $62,6-64,9$ & 74,6 & 0,2 & 2,7 & 3,6 & $74,0-75,1$ & 0,85 \\
\hline Capparis flexuosa & 28,9 & 0,2 & 1,9 & 6,6 & $28,5-29,3$ & 26,3 & 0,1 & 1,8 & 6,9 & $25,9-26,7$ & 1,09 \\
\hline Maytenus communis & 20,1 & 0,1 & 1,6 & 7,8 & $19,8-20,4$ & 18,4 & 0,1 & 1,4 & 7,8 & $18,1-18,6$ & 1,09 \\
\hline Maytenus robusta & 24,4 & 0,1 & 1,1 & 4,4 & $24,2-24,6$ & 21,0 & 0,1 & 1,3 & 6,0 & $20,8-21,2$ & 1,16 \\
\hline Erythroxylum cuspidifolium & 39,2 & 0,6 & 2,5 & 6,3 & $38,2-40,3$ & 35,0 & 0,4 & 2,2 & 6,4 & $34,1-35,9$ & 1,12 \\
\hline Erythroxylum pulchrum & 25,1 & 0,3 & 2,4 & 9,5 & $24,5-25,8$ & 28,7 & 0,2 & 1,7 & 6,0 & $28,3-29,2$ & 0,87 \\
\hline Margaritaria nobilis & 29,1 & 0,5 & 2,3 & 7,9 & $28,1-30,0$ & 23,7 & 0,7 & 3,6 & 15,2 & $22,2-25,2$ & 1,23 \\
\hline Sebastiania multiramea & 20,5 & 0,2 & 0,8 & 3,8 & $20,1-20,8$ & 17,6 & 0,2 & 1,2 & 7,0 & $17,1-18,1$ & 1,16 \\
\hline Sebastiania serrata & 22,8 & 0,3 & 1,3 & 5,5 & $22,3-23,3$ & 17,2 & 0,3 & 1,3 & 7,7 & $16,7-17,8$ & 1,32 \\
\hline Casearia comersoniana & 44,0 & 0,1 & 0,6 & 1,5 & $43,9-44,1$ & 25,1 & 0,1 & 1,9 & 7,5 & $24,7-25,4$ & 1,75 \\
\hline Casearia sylvestris & 26,8 & 0,2 & 2,1 & 7,8 & $26,4-27,3$ & 20,4 & 0,3 & 3,3 & 16,1 & $19,7-21,1$ & 1,31 \\
\hline Cariniana ianeirensis & 27,8 & 0,1 & 1,6 & 5,8 & $27,5-28,1$ & 20,4 & 0,1 & 1,0 & 4,8 & $20,2-20,6$ & 1,36 \\
\hline Caesalpinia echinata & 49,1 & 0,6 & 3,0 & 6,2 & $47,9-50,4$ & 55,7 & 0,5 & 2,7 & 4,9 & $54,6-56,8$ & 0,84 \\
\hline Machaerium aculeatum & 21,9 & 0,1 & 1,3 & 5,9 & $21,7-22,2$ & 17,3 & 0,1 & 0,3 & 1,9 & $17,2-17,3$ & 1,26 \\
\hline Pterocarpus rohrii & 25,0 & 0,1 & 1,3 & 5,0 & $24,8-25,2$ & 19,4 & 0,1 & 0,6 & 3,2 & $19,3-19,5$ & 1,28 \\
\hline Swartzia myrtifolia & 34,5 & 0,1 & 1,6 & 4,7 & $34,2-34,8$ & 23,6 & 0,1 & 0,9 & 4,0 & $23,4-23,8$ & 1,46 \\
\hline Sorocea bonplandii & 21,7 & 0,1 & 1,4 & 6,7 & $21,4-21,9$ & 21,6 & 0,1 & 1,1 & 5,1 & $21,4-21,8$ & 1,00 \\
\hline Myrsine umbellata & 27,0 & 0,1 & 1,6 & 5,8 & $26,7-27,2$ & 24,5 & 0,1 & 0,5 & 1,8 & $24,4-24,6$ & 1,10 \\
\hline Campomanesia eugenioides & 13,1 & 0,1 & 0,9 & 6,7 & $13,0-13,3$ & 25,6 & 0,1 & 0,9 & 3,4 & $25,5-25,8$ & 0,51 \\
\hline Eugenia maroviana & 14,6 & 0,2 & 2,6 & 17,8 & $14,1-15,1$ & 17,5 & 0,1 & 1,3 & 7,1 & $17,3-17,7$ & 0,83 \\
\hline Syzygium cumini & 10,6 & 0,1 & 0,9 & 8,3 & $10,5-10,8$ & 18,1 & 0,1 & 0,1 & 0,5 & $18,0-18,1$ & 0,58 \\
\hline Guapira hirsuta & 34,3 & 0,1 & 1,8 & 5,1 & $34,1-34,7$ & 31,5 & 0,3 & 6,7 & 21,3 & $30,3-32,7$ & 1,09 \\
\hline Guapira opposita & 44,2 & 0,1 & 0,8 & 1,8 & $44,0-44,3$ & 44,7 & 0,1 & 0,1 & 0,2 & $44,7-44,9$ & 0,98 \\
\hline Ouratea stipulata & 19,6 & 0,1 & 0,1 & 0,5 & $19,5-19,6$ & 20,3 & 0,1 & 0,4 & 1,7 & $20,2-20,3$ & 0,96 \\
\hline Seguieria floribunda & 31,9 & 0,1 & 0,9 & 2,8 & $31,7-32,0$ & 26,6 & 0,2 & 4,9 & 18,3 & $25,7-27,4$ & 1,20 \\
\hline Coutarea hexandra & 35,2 & 0,1 & 0,6 & 1,8 & $35,1-35,3$ & 39,1 & 0,1 & 0,4 & 1,1 & $39,0-39,1$ & 0,90 \\
\hline Psychotria carthagenensis & 40,8 & 0,5 & 2,5 & 6,3 & $39,7-41,8$ & 42,6 & 0,2 & 4,0 & 9,4 & $41,9-43,3$ & 0,95 \\
\hline Pilocarpus spicatus & 31,8 & 0,1 & 2,3 & 7,2 & $31,3-32,2$ & 20,3 & 0,1 & 0,4 & 1,7 & $20,2-20,3$ & 1,56 \\
\hline
\end{tabular}


Tabela 2. Médias das medidas $(\mu \mathrm{m})$ das aberturas e da exina dos grãos de pólen de espécies arbóreas da APA da Serra da Capoeira Grande, Maciço da Pedra Branca, Rio de Janeiro (n=10): Comp.- comprimento; Larg.- largura; D1- diâmetro 1; D2- diâmetro 2.

\begin{tabular}{|c|c|c|c|c|c|c|c|c|c|c|}
\hline \multirow[t]{2}{*}{ Espécies } & \multicolumn{3}{|c|}{ Colpo } & \multicolumn{2}{|c|}{ Endoabertura } & \multicolumn{2}{|c|}{ Espessura da Exina } & \multicolumn{3}{|c|}{ Poro } \\
\hline & Larg. & Comp. & $\begin{array}{c}\text { Margem/ } \\
\text { Costa }\end{array}$ & Larg & Comp & Sexina & Nexina & D1 & D2 & $\begin{array}{l}\text { Ânulo/ } \\
\text { Áspide }\end{array}$ \\
\hline Astronium fraxinifolium & 2,1 & 21,7 & $\operatorname{sim}$ & 3,0 & 7,4 & 1,36 & 0,36 & ----- & ----- & ----- \\
\hline Spondias lutea & 0,9 & 25,3 & ----- & 1,1 & 7,4 & 0,73 & 0,38 & ----- & ----- & ----- \\
\hline Peschiera laeta & 2,5 & 15,2 & ----- & 5,4 & 15,4 & 2,13 & 0,66 & ----- & ----- & ----- \\
\hline Jacaranda micrantha & 5,6 & 38,8 & ----- & ----- & ----- & 1,36 & 0,91 & ----- & ----- & ----- \\
\hline Sparattosperma leucanthum & ----- & ----- & ----- & ----- & ----- & 3,62 & 1,02 & ----- & ----- & ----- \\
\hline Tabebuia impetiginosa & 6,0 & 29,0 & ----- & ----- & ----- & 2,08 & 0,88 & ----- & ----- & ----- \\
\hline Bombacopsis glabra & 1,4 & 21,6 & $\operatorname{sim}$ & $\operatorname{sim}$ & $\operatorname{sim}$ & 3,80 & 0,93 & ----- & ----- & ----- \\
\hline Chorisia speciosa & 2,8 & 14,2 & $\operatorname{sim}$ & $\operatorname{sim}$ & $\operatorname{sim}$ & 4,65 & 0,63 & ----- & ----- & ----- \\
\hline Pseudobombax grandiflorum & 5,6 & 12,5 & $\operatorname{sim}$ & $\operatorname{sim}$ & $\operatorname{sim}$ & 1,08 & 0,55 & ---- & ----- & ----- \\
\hline Capparis flexuosa & 3,4 & 24,5 & $\operatorname{sim}$ & 2,8 & 6,2 & 0,69 & 0,48 & ----- & ---- & ----- \\
\hline Maytenus communis & 1,2 & 13,0 & $\operatorname{sim}$ & 1,2 & 3,4 & 1,38 & 0,65 & ----- & ----- & ----- \\
\hline Maytenus robusta & 0,9 & 15,2 & $\operatorname{sim}$ & 1,2 & 4,3 & 1,95 & 0,83 & ----- & ----- & ----- \\
\hline Erythroxylum cuspidifolium & 2,4 & 27,6 & $\operatorname{sim}$ & 4,5 & 9,0 & 1,13 & 0,93 & ----- & ----- & ----- \\
\hline Erythroxylum pulchrum & 1,9 & 19,1 & $\operatorname{sim}$ & 3,3 & 9,8 & 1,23 & 0,45 & ----- & ----- & ----- \\
\hline Margaritaria nobilis & 0,7 & 18,9 & ----- & 2,6 & 3,7 & 0,78 & 0,68 & ----- & ----- & ----- \\
\hline Sebastiania multiramea & 1,9 & 15,0 & $\operatorname{sim}$ & 2,4 & 2,8 & 0,93 & 0,80 & ----- & ----- & ----- \\
\hline Sebastiania serrata & 1,7 & 15,8 & $\operatorname{sim}$ & 2,2 & 2,8 & 1,00 & 0,45 & ----- & ----- & ----- \\
\hline Casearia comersoniana & 1,1 & 30,1 & ----- & 2,3 & 11,5 & 2,00 & 1,00 & ---- & ---- & ---- \\
\hline Casearia sylvestris & 1,6 & 19,4 & ----- & 1,4 & 4,5 & 1,00 & 0,53 & ----- & ----- & ---- \\
\hline Ocotea divaricata & ----- & ----- & ----- & ----- & ----- & 0,59 & 0,33 & ----- & ----- & ----- \\
\hline Cariniana ianeirensis & 1,7 & 21,9 & $\operatorname{sim}$ & 2,1 & 5,6 & 1,13 & 0,63 & ---- & ---- & ----- \\
\hline Caesalpinia echinata & 3,6 & 16,2 & $\operatorname{sim}$ & 9,9 & 4,9 & 2,90 & 2,20 & ---- & ---- & ---- \\
\hline Machaerium aculeatum & 0,8 & 14,8 & ----- & 3,7 & 4,6 & 0,90 & 0,28 & ---- & ---- & ----- \\
\hline Pterocarpus rohrii & 1,8 & 17,4 & $\operatorname{sim}$ & 5,1 & 4,7 & 1,05 & 0,58 & ----- & ----- & ----- \\
\hline Swartzia myrtifolia & 0,9 & 22,9 & $\operatorname{sim}$ & 1,5 & 7,4 & 1,75 & 0,52 & ----- & ----- & ----- \\
\hline Sorocea bonplandii & ----- & ---- & ----- & ----- & ----- & 0,45 & 0,30 & 2,8 & 2,9 & $\operatorname{sim}$ \\
\hline Myrsine umbellata & 3,3 & 12,5 & $\operatorname{sim}$ & ----- & ----- & 0,65 & 0,32 & ----- & ----- & ----- \\
\hline Campomanesia eugenioides & ----- & ----- & ----- & ----- & ----- & 0,50 & 0,30 & ----- & ----- & ----- \\
\hline Eugenia maroviana & ----- & ----- & ----- & ----- & ----- & 0,65 & 0,38 & ----- & ----- & ----- \\
\hline Syzygium cumini & ----- & ----- & ----- & ----- & ----- & 0,38 & 0,38 & ---- & ---- & ----- \\
\hline Guapira hirsuta & 1,4 & 24,7 & ---- & ---- & ---- & 1,00 & 0,48 & ----- & ----- & ---- \\
\hline Guapira opposita & 1,2 & 27,7 & ----- & ----- & ----- & 1,15 & 0,53 & ----- & ----- & ----- \\
\hline Ouratea stipulata & 2,3 & 12,7 & $\operatorname{sim}$ & 2,4 & 4,0 & 0,55 & 0,40 & ---- & ----- & ----- \\
\hline Seguieria floribunda & 1,2 & 23,1 & ----- & ---- & ----- & 0,63 & 0,33 & ---- & ---- & ----- \\
\hline Coutarea hexandra & 14,4 & 13,7 & ---- & ---- & ---- & 1,25 & 0,40 & ---- & ----- & ---- \\
\hline Psychotria carthagenensis & 9,3 & 24,4 & ----- & ----- & ----- & 1,18 & 0,45 & ----- & ----- & ----- \\
\hline Pilocarpus spicatus & 0,7 & 22,2 & ----- & 1,0 & 6,5 & 0,80 & 0,35 & ---- & ---- & ----- \\
\hline
\end{tabular}

Tabela 3. Médias das medidas $(\mu \mathrm{m})$ dos diâmetros dos grãos de pólen apolares de espécies arbóreas da APA da Serra da Capoeira Grande, Maciço da Pedra Branca, Rio de Janeiro (n=10): x- média aritmética; sx- desvio padrão da média; s- desvio padrão da amostra; CV\%- coeficiente de variabilidade; IC95\%- intervalo de confiança a $95 \%$.

\begin{tabular}{|c|c|c|c|c|c|}
\hline \multirow[t]{2}{*}{ Espécies } & \multicolumn{5}{|c|}{ Diâmetro I } \\
\hline & $\mathrm{x}$ & $\mathrm{s}_{\underline{\underline{x}}}$ & $\mathrm{~s}$ & $\mathrm{CV} \%$ & IC95\% \\
\hline $\begin{array}{l}\text { Sparattosperma } \\
\text { leucanthum }\end{array}$ & 38,8 & 0,5 & 2,3 & 5,9 & $37,8-39,7$ \\
\hline Ocotea divaricata & 14,9 & 0,5 & 3,8 & 25,5 & $13,9-15,9$ \\
\hline
\end{tabular}



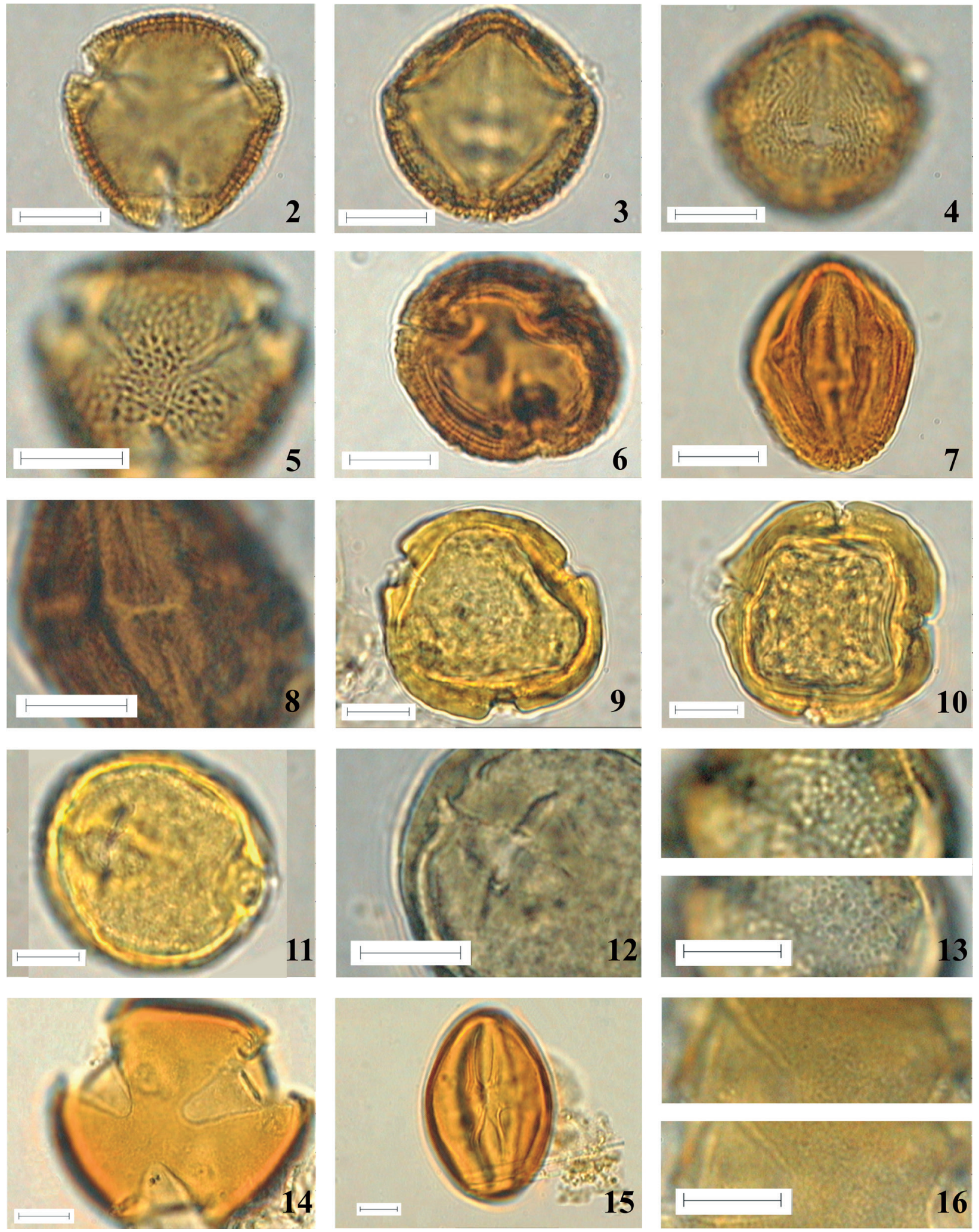

Figs. 2-16. 2-5. Astronium fraxinifolium. 2. Vista polar; 3. Vista equatorial; 4. Vista equatorial, detalhe da endoabertura; 5. Detalhe da ornamentação da superfície. 6-8. Spondias lutea. 6. Vista polar; 7. Vista equatorial; 8. Detalhe da abertura. 9-13. Peschiera laeta. 9. Vista polar, grão de pólen 3-colporado; 10. Vista polar, grão de pólen 4-colporado; 11. Vista equatorial, grão de pólen 3-colporado; 12. Detalhe da abertura; 13. Ornamentação da superfície, primeiro e segundo focos de visualização. 14-16. Jacaranda macrantha. 14. Vista polar; 15. Vista equatorial; 16. Ornamentação da superfície, primeiro e segundo focos de visualização. Barras $=10 \mu \mathrm{m}$. 
arredondadas e bem definidas da sexina; exina de 3,25$7,00 \mu \mathrm{m}$ de espessura, sexina reticulada, heterobrocada, muito mais espessa do que a nexina.

Material examinado: BRASIL, RIO DE JANEIRO, Macaé, 19.XII.2000, J.F.A. Baumgratz, L.C. Giordano, M. Bovini \& J.C. Silva 753 (RB424009).

Tabebuia impetiginosa (Mart. ex DC.) Standl. (nome válido Handroanthus impetiginosus (Mart. ex DC.) Mattos)

(Pr. 2, Figs. 20 - 23)

Grãos de pólen de tamanho médio, isopolares, subprolatos, âmbito circular; 3-zono-colpados, colpos longos e largos, mas muito largos nas porções subequatoriais; presença de poucos grãos de pólen sincolpados; exina de 2,75-3,15 $\mu \mathrm{m}$ de espessura, sexina reticulada, homobrocada, com o dobro de espessura da nexina.

Material examinado: BRASIL, SÃO PAULO, Campinas, 30.V.1967, W. Hoehne 6209 (SP119808).

Bombacaceae (Malvaceae/Bombacoideae)

Bombacopsis glabra (Pasq.) A. Robyns (nome válido Pachira glabra Pasq.)

$$
\text { (Pr. 2, Figs. } 24 \text { - 28) }
$$

Grãos de pólen de tamanho grande, isopolares, prolatoesferoidais, planaperturado, âmbito subtriangular; 3-zonocolporados, cólporos curtos e estreitos, com margem psilada seguida de estreita faixa microrreticulada, endoabertura lolongada, de difícil visualização, não excedendo a margem dos colpos; exina de 4,55-4,90 $\mu \mathrm{m}$ de espessura, sexina reticulada com muros com espículos e calotas equatoriais microrreticuladas, muito mais espessa do que a nexina.

Material examinado: BRASIL, RIO DE JANEIRO, Pedra de Guaratiba, 22.VIII.2001, G.L. Peixoto \& M.V.O. Muniz 24 (RB365117).

Chorisia speciosa A. St.-Hil. (nome válido Ceiba speciosa (A. St.-Hil.) Ravenna)

(Pr. 2, Figs. 29 - 31, Pr. 3, Fig. 32)

Grãos de pólen de tamanho grande, isopolares, prolatoesferoidais, âmbito circular, 4-(5)-zono-colporados, cólporos muito curtos e estreitos, com margem estreita, endoabertura lolongada, de difícil visualização, não

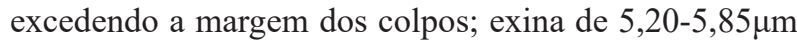
de espessura, sexina reticulada com espículos sobre os muros, muito mais espessa do que a nexina.

Material examinado: BRASIL, RIO DE JANEIRO, Pedra de Guaratiba, 13.II.2001, G.L. Peixoto, M.V.O. Muniz \& F.A.A. Passeri 21 (RB365118).

Pseudobombax grandiflorum (Cav.) A. Robyns (Pr. 3, Figs. 33 - 37)
Grãos de pólen de tamanho grande, isopolares, suboblatos, pleurotremados, âmbito triangular; 3-zonocolporados, cólporos muito curtos e largos, endoabertura lolongada, de difícil visualização, não excedendo a margem dos colpos; exina de 1,50-1,83 $\mu \mathrm{m}$ de espessura, sexina reticulada, heterobrocada, com calotas equatoriais microrreticuladas, com o dobro de espessura da nexina, sexina mais espessa na região das aberturas.

Material examinado: BRASIL, SÃO PAULO, Itapecerica da Serra, s.d., M.C. Duarte 41 \& G.L. Esteves (SP372106).

Capparaceae

Capparis flexuosa (L.) L. (nome válido Cynophalla flexuosa (L.) J. Presl.)

$$
\text { (Pr. 3, Figs. } 38 \text { - 41) }
$$

Grãos de pólen de tamanho médio, isopolares, prolatoesferoidais, âmbito subcircular, 3-zono-colporados, cólporos longos e estreitos, com margem estreita e membrana apertural, endoabertura lalongada, com extremidades arredondadas; exina de $0,85-1,40 \mu \mathrm{m}$ de espessura, sexina microrreticulada, homobrocada, um pouco mais espessa do que a nexina.

Material examinado: BRASIL, PERNAMBUCO, 18.III.1924, D. Bento Peckel 14494 (SP14494).

\section{Celastraceae}

Maytenus communis Reissek

$$
\text { (Pr. 3, Figs. } 42 \text { - 45) }
$$

Grãos de pólen de tamanho pequeno, isopolares, prolato-esferoidais, âmbito subcircular, 3-zono-colporados, cólporos longos e estreitos, com constrição mediana e margem estreita, endoabertura lalongada, com leve constrição mediana e extremidades alargadas; exina de $1,85-2,20 \mu \mathrm{m}$ de espessura, sexina microrreticulada, com o dobro de espessura da nexina.

Material examinado: BRASIL, SÃO PAULO, Jundiaí, 28.IX.1994, S.L.J. Mendaçoli, E.G. Cardoso \& A.M.C. Silva 645 (SP272049).

Maytenus robusta Reissek (nome válido Maytenus gonoclada Mart.)

$$
\text { (Pr. 3, Fig. 46, Pr. 4, Figs. } 47 \text { - 49) }
$$

Grãos de pólen de tamanho pequeno, isopolares, subprolatos, âmbito subcircular, 3-zono-colporados, cólporos longos e estreitos, com constrição mediana e margem estreita, endoabertura lalongada, com leve constrição mediana e extremidades alargadas; exina de $2,75-2,80 \mu \mathrm{m}$ de espessura, sexina microrreticulada com o dobro de espessura da nexina.

Material examinado: BRASIL, RIO DE JANEIRO, Nova Friburgo, 27.XII.1989, M. Nadruz et al. 524 (SP266134). 

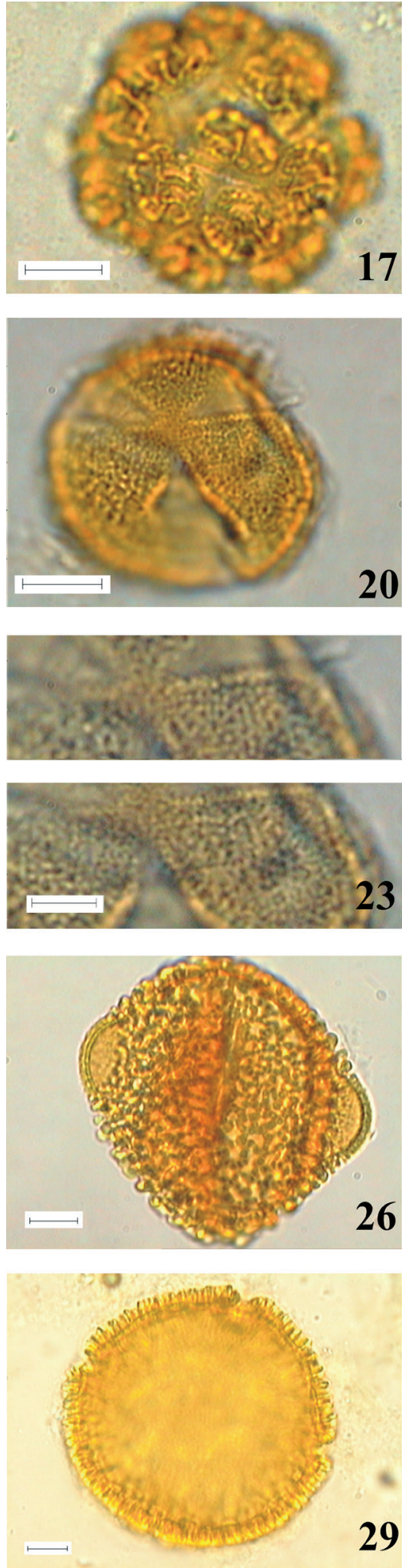
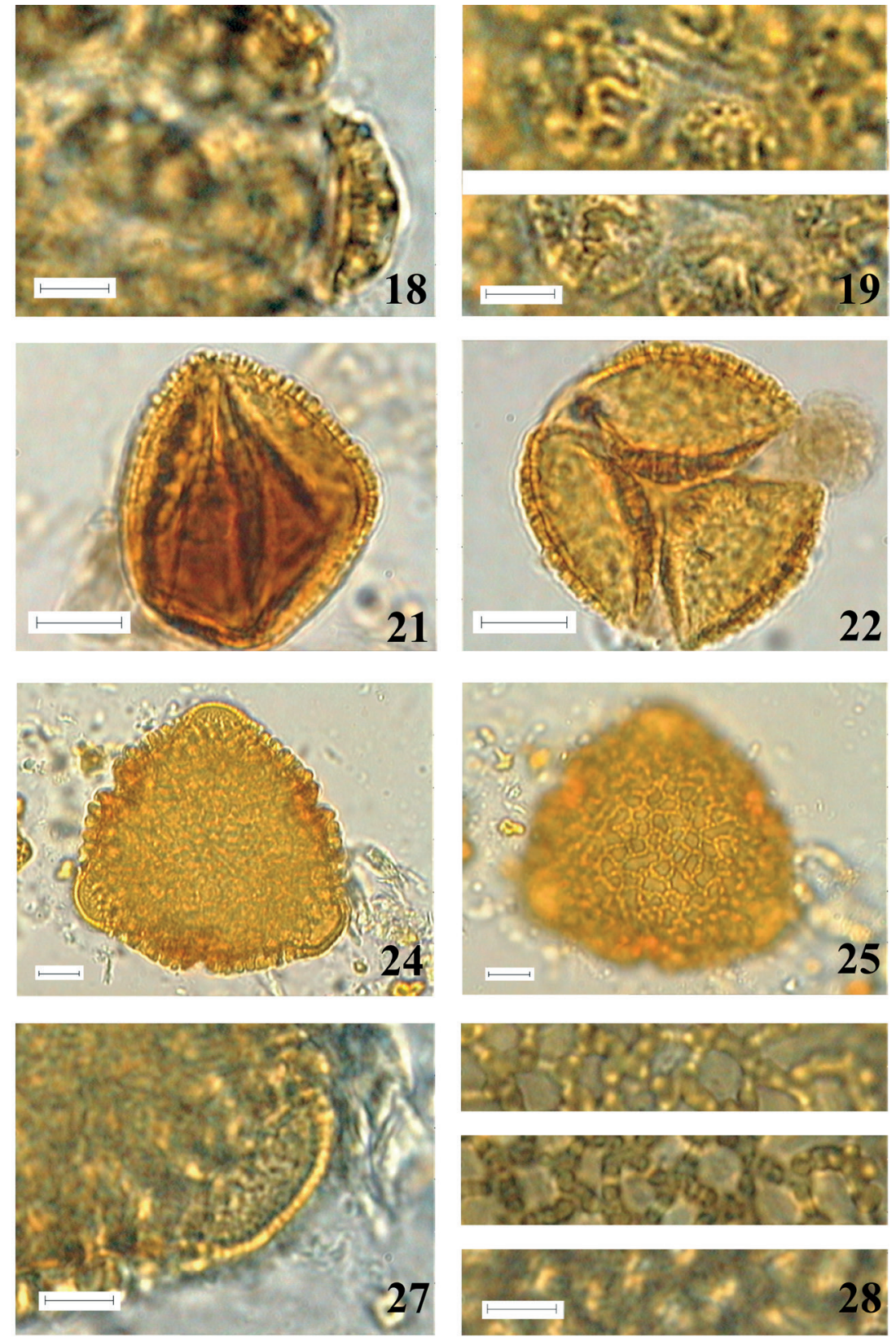

30

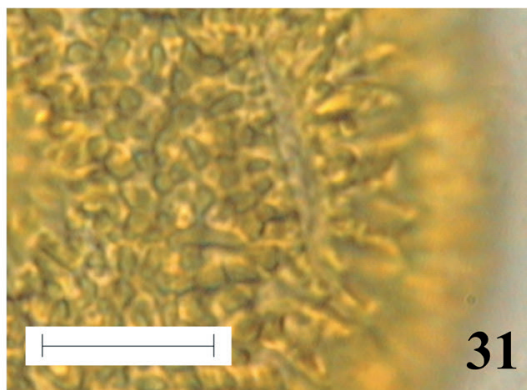

Figs. 17-31. 17-19. Sparattosperma leucanthum. 17. Vista geral do grão de pólen; 18. Corte óptico da exina; 19. Ornamentação da superfície, primeiro e segundo focos de visualização. 20-23. Tabebuia impetiginosa. 20. Vista polar; 21. Vista equatorial; 22. Vista polar do grão de pólen sincolpado; 23. Ornamentação da superfície, primeiro e segundo focos de visualização. 24-28. Bombacopsis glabra. 24. Vista polar; 25. Vista polar, detalhe da superfície; 26. Vista equatorial; 27. Ornamentação da superfície na região do mesocolpo; 28. Ornamentação da superfície, primeiro, segundo e terceiro focos de visualização. 29-31. Chorisia speciosa. 29. Vista polar; 30. Vista equatorial; 31. Detalhe da ornamentação da superfície e cólporo. Barras: Figs. 18, 19, 23, 27, $28=5 \mu \mathrm{m}$; Figs. 17, 20, 21, 22, 24, 25, 26, 29, 20, $31=10 \mu \mathrm{m}$. 

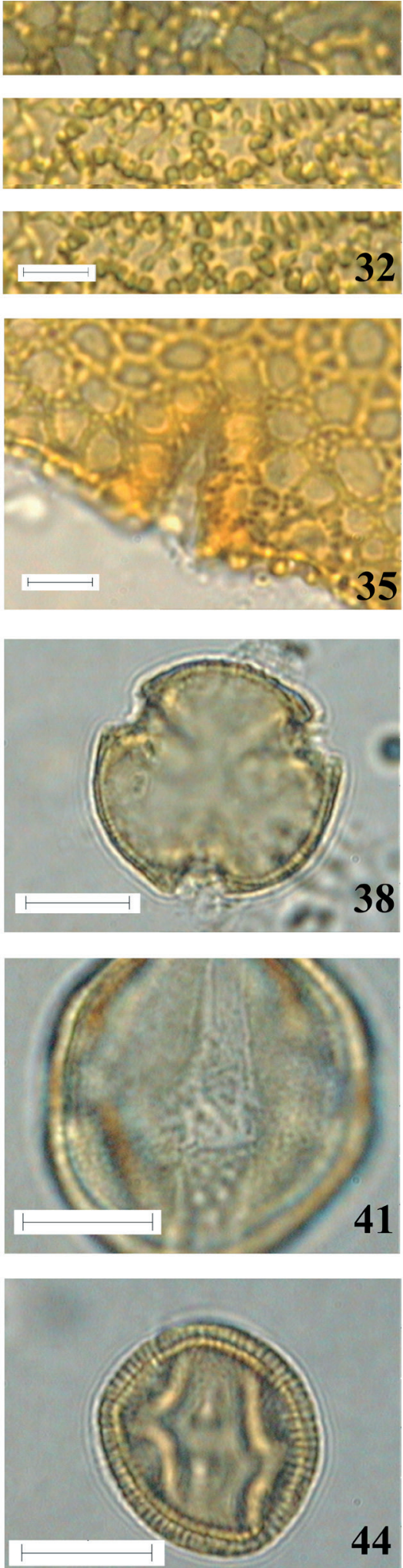

44
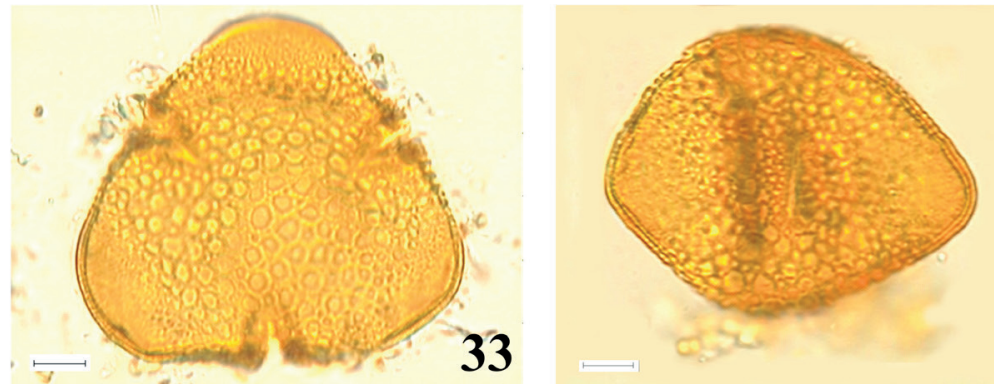

34
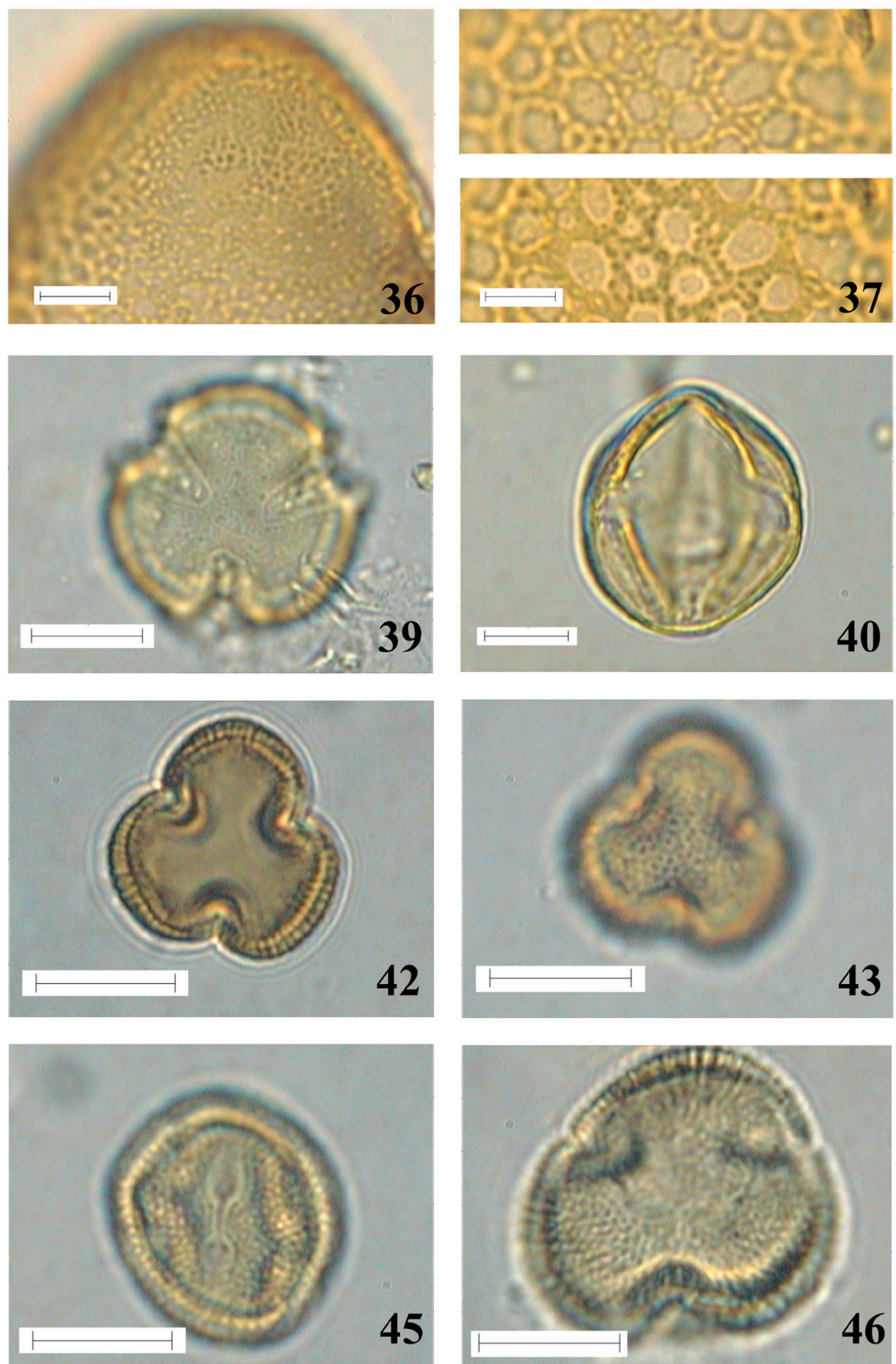

Figs. 32-46. 32. Chorisia speciosa. Ornamentação da superfície, primeiro, segundo e terceiro focos de visualização. 33-37. Pseudobombax grandiflorum. 33. Vista polar; 34. Vista equatorial; 35. Detalhe da abertura; 36. Ornamentação da superfície no mesocolpo; 37. Ornamentação da superfície no apocolpo, primeiro e segundo focos de visualização. 38-41. Capparis flexuosa. 38. Vista polar; 39. Vista polar, detalhe da superfície; 40. Vista equatorial; 41. Detalhe da abertura. 42-45. Maytenus communis. 42. Vista polar; 43. Vista polar, detalhe da superfície; 44. Vista equatorial; 45. Detalhe da abertura. 46. Maytenus robusta. Vista polar. Barras: Figs. 32, 35, 36, $37=5 \mu \mathrm{m}$; Figs. 33, 34, 38- 46 $=10 \mu \mathrm{m}$. 
Erythroxylaceae

Erythroxylum cuspidifolium Mart.

(Pr. 4, Figs. 50 - 54)

Grãos de pólen de tamanho médio, isopolares, prolatoesferoidais, âmbito subcircular, 3-zono-colporados, cólporos longos e estreitos, com margem estreita, endoabertura lalongada, com extremidades arredondadas; presença de poucos grãos de pólen sincolpados; exina de 1,90-2,20 $\mu \mathrm{m}$ de espessura, sexina reticulada, homobrocada, mais espessa do que a nexina.

Material examinado: BRASIL, RIO DE JANEIRO: Pedra de Guaratiba, 27.XI.2001, G.L. Peixoto \& M.V.O. Muniz 51 (RB365797).

\section{Erythroxylum pulchrum A. St.-Hil}

(Pr. 4, Figs. 55 - 57)

Grãos de pólen de tamanho médio, isopolares, suboblatos, âmbito subcircular, 3-zono-colporados, cólporos longos e estreitos, com margem estreita, endoabertura lalongada, com extremidades afiladas; exina de 1,25$2,30 \mu \mathrm{m}$ de espessura, sexina reticulada, mais espessa do que a nexina.

Material examinado: BRASIL, SÃO PAULO, Ubatuba, 16.XI.1993, F. Barros 2888 (SP275204).

Euphorbiaceae

Margaritaria nobilis L. f.

(Pr. 4, Figs. 58 - 61)

Grãos de pólen de tamanho pequeno a médio, isopolares, subprolatos, âmbito subcircular, 3-zono-colporados, cólporos longos e estreitos com extremidades afiladas, endoabertura lalongada, com extremidades arredondadas; exina de 1,40-1,50 $\mu \mathrm{m}$ de espessura, sexina microrreticulada, um pouco mais espessa do que a nexina.

Material examinado: BRASIL, RIO DE JANEIRO, Armação de Búzios, 27.VIII.2004, H.G. Dantas, C.F. Sá \& R.D. Ribeiro $s / n^{\circ}$ (RB414063).

Sebastiania multiramea Mull. Arg (nome válido Gymnanthes multiramea (Klotzsch) Müll. Arg.)

(Pr. 5, Figs. 62 - 65)

Grãos de pólen de tamanho pequeno, isopolares, subprolatos, âmbito subcircular, 3-zono-colporados, cólporos longos e estreitos, com margem estreita, endoabertura circular; exina de 1,40-2,05 $\mu \mathrm{m}$ de espessura, sexina microrreticulada, um pouco mais espessa do que a nexina. Material examinado: BRASIL, RIO DE JANEIRO: Parque Nacional da Tijuca, 29.I.2000, J.M.A. Braga 5769 (RB381853).

Sebastiania serrata (Baill. Ex Mull. Arg.) Mull. Arg (nome válido Gymnanthes serrata Baill. ex Müll. Arg.)

(Pr. 5, Figs. 66 - 69)
Grãos de pólen de tamanho pequeno, isopolares, subprolatos, âmbito subcircular, 3-zono-colporados, cólporos longos e estreitos, com margem estreita, endoabertura circular; exina de 1,45-1,82 $\mu \mathrm{m}$ de espessura, sexina microrreticulada, muito mais espessa do que a nexina.

Material examinado: BRASIL, RIO DE JANEIRO, Campo Grande, 04.IV.1978, G. Martinelli et al. 4135 (RB205082).

Flacourtiaceae (Salicaceae)

Casearia commersoniana Cambessedes

(Pr. 5, Figs. 70 - 72)

Grãos de pólen de tamanho médio, isopolares, prolatos, âmbito subcircular, 3-zono-colporados, cólporos longos e estreitos, sem margem, endoabertura lalongada, com extremidades afiladas; exina de 2,92-3,33 $\mu$ m de espessura, sexina reticulada, com o dobro da espessura da nexina.

Material examinado: BRASIL, RIO DE JANEIRO, Pedra de Guaratiba, 07.XI.2001, G.L. Peixoto \& M.V.O. Muniz 33 (RB366125).

\section{Casearia sylvestris Sw.}

$$
\text { (Pr. 5, Figs. } 73 \text { - 75) }
$$

Grãos de pólen de tamanho pequeno a médio, isopolares, subprolatos, âmbito subcircular, 3-zono-colporados, cólporos longos e estreitos, endoabertura lalongada, com extremidades afiladas; exina de 1,33-1,75 $\mu \mathrm{m}$ de espessura, sexina psilada, com o dobro da espessura da nexina.

Material examinado: BRASIL, ESPÍRITO SANTO, Santa Teresa, 10.VII.2002, R.R. Vervloet 441 \& W. Pizziolo (RB380713).

Lauraceae

Ocotea divaricata (Nees) $\mathrm{Mez}$

(Pr. 5, Fig. 76, Pr. 6, Fig.77)

Grãos de pólen de tamanho pequeno, apolares, esferoidais, inaperturados; exina de 0,70-1,10 $\mu \mathrm{m}$ de espessura, sexina espiculada, um pouco mais espessa do que a nexina.

Material examinado: BRASIL, RIO DE JANEIRO, Parque Nacional da Tijuca, 20.XII.1962, C. Angeli 342 (SP99679).

Lecythidaceae

Cariniana ianeirensis $\mathrm{R}$. Knuth

$$
\text { (Pr. 6, Figs. } 78 \text { - 81) }
$$

Grãos de pólen de tamanho médio, isopolares, prolatos, âmbito subcircular, frequentemente colpados, raramente 3-zono-colporados, colpos longos e estreitos com extremidades afiladas, com margem estreita, levemente constrictos equatorialmente, endoabertura lalongada, com extremidades arredondadas; exina de 1,70-1,75 $\mu \mathrm{m}$ de 

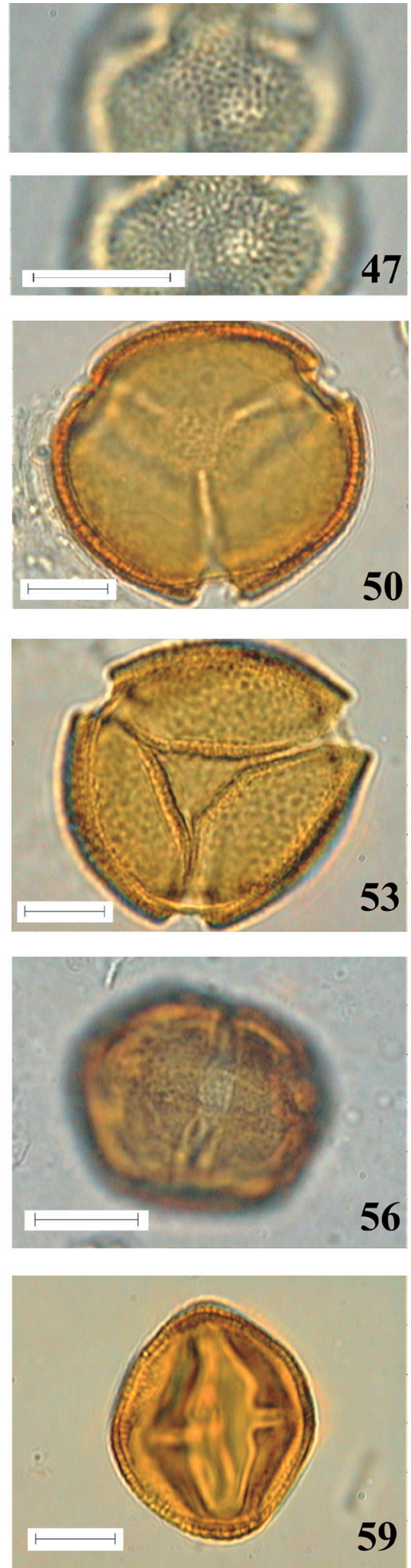
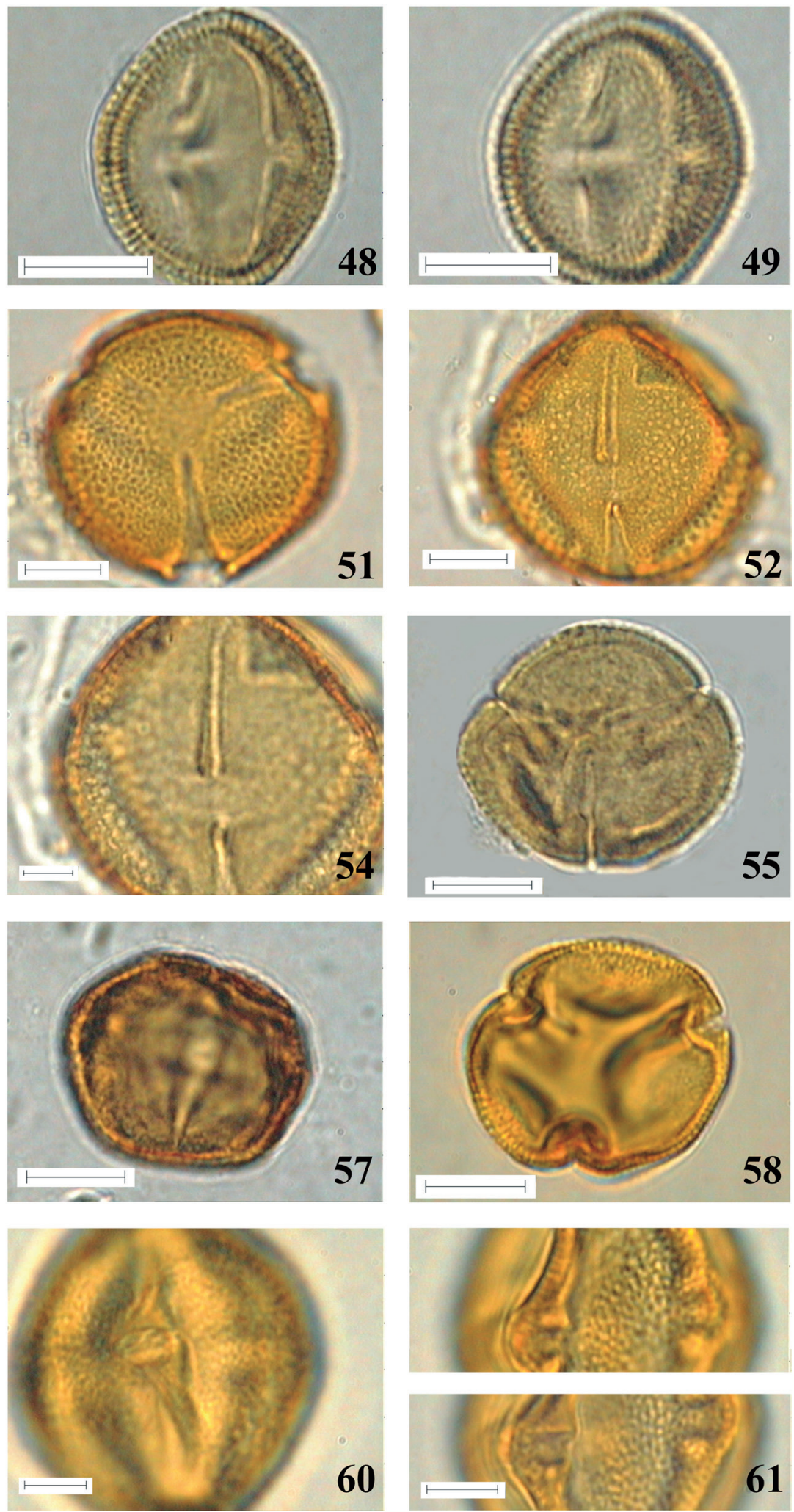

Figs. 47-61. 47-49. Maytenus robusta. 47. Ornamentação da superfície, primeiro, segundo e terceiro focos de visualização; 48. Vista equatorial; 49. Detalhe da abertura. 50-54. Erythroxylum cuspidifolium. 50. Vista polar; 51. Vista polar, detalhe da superfície; 52. Vista equatorial; 53. Vista polar, grão de pólen sincolpado; 54. Detalhe da abertura. 55-57. Erythoxylum pulchrum. 55. Vista polar; 56. Vista equatorial, detalhe da abertura; 57. Vista equatorial. 58-61. Margaritaria nobilis. 58. Vista polar; 59. Vista equatorial; 60. Vista equatorial, detalhe da abertura; 61. Ornamentação da superfície, primeiro e segundo focos de visualização. Barras: Figs. 54, 60, $61=5 \mu \mathrm{m}$; Figs. 47-53, 55-59 $=10 \mu \mathrm{m}$. 

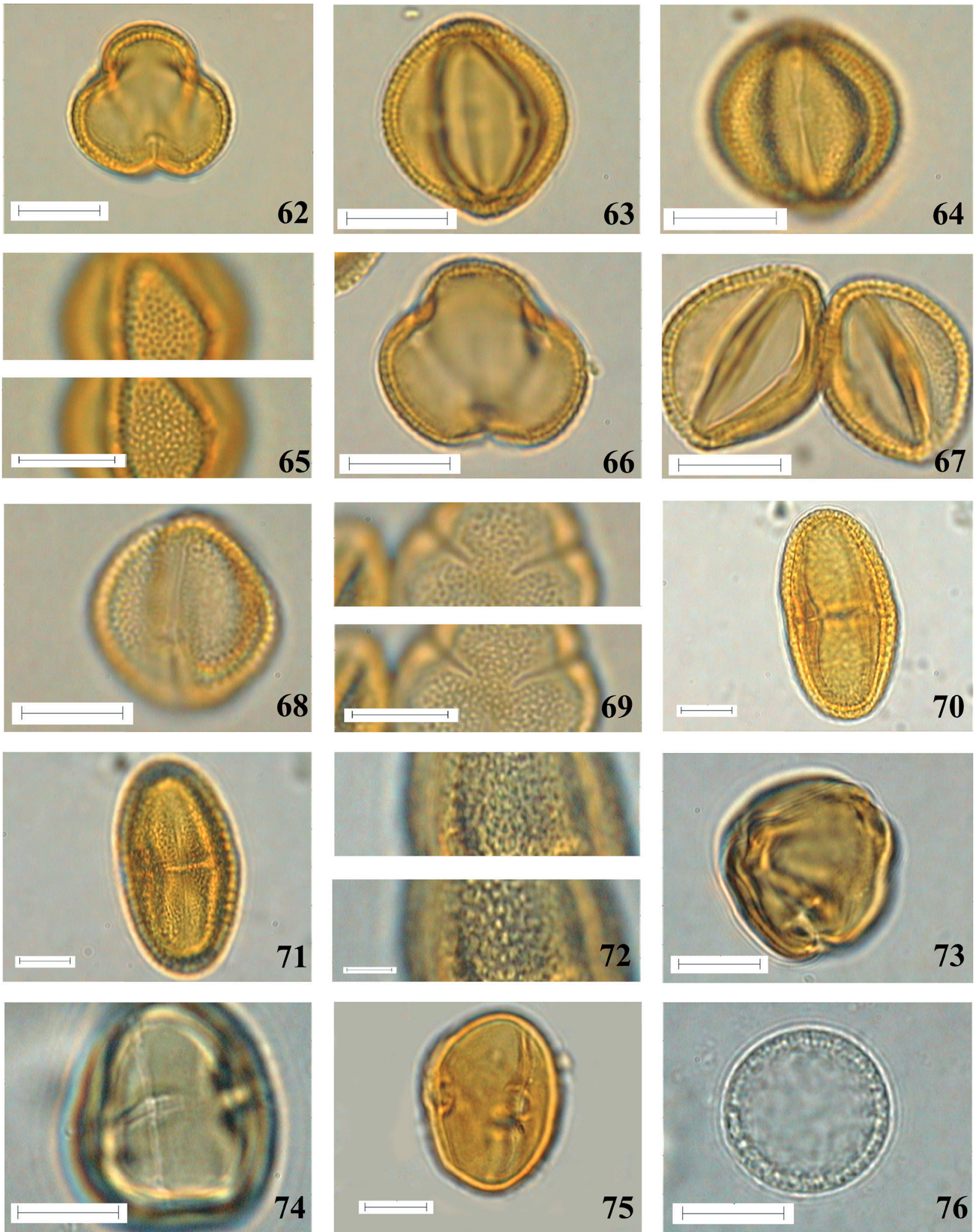

Figs. 62-76. 62-65. Sebastiania multiramea. 62. Vista polar; 63. Vista equatorial; 64. Vista equatorial, detalhe da endoabertura; 65. Ornamentação da superfície, primeiro e segundo focos de visualização. 66- 69. Sebastiania serrata. 66. Vista polar; 67. Vista equatorial de dois grãos de pólen; 68. Vista equatorial, detalhe da abertura; 69. Ornamentação da superfície, primeiro e segundo focos de visualização. 70-72. Casearia commersoniana. 70. Vista equatorial; 71. Vista equatorial, detalhe da abertura; 72. Ornamentação da superfície, primeiro e segundo focos de visualização. 73-75. Casearia sylvestris. 73. Vista polar, inclinada; 74. Vista equatorial, detalhe da abertura; 75. Vista equatorial. 76. Ocotea divaricata. Vista geral do grão de pólen. Barras: Fig. $72=5 \mu \mathrm{m}$; Figs. 62-71, 73-76 = $10 \mu \mathrm{m}$. 
espessura, sexina reticulada, homobrocada, com o dobro da espessura da nexina.

Material examinado: BRASIL, MATO GROSSO: Araputanga, 27.XI.1995, G. Hatschbach, A. Pott, V. Pott \& E. Barbosa 63397 (RB377078).

Leguminosae/Caesalpinioideae

Caesalpinia echinata Lam.

$$
\text { (Pr. 6, Figs. } 82 \text { - 84) }
$$

Grãos de pólen de tamanho médio a grande, isopolares, suboblatos, âmbito circular, 3-zono-colporados, cólporos curtos e estreitos, com margem microrreticulada muito larga, endoabertura lolongada; exina de 4,83-5,15 $\mu \mathrm{m}$ de espessura, sexina reticulada, heterobrocada, retículos menores nos pólos, um pouco mais espessa do que a nexina. Material examinado: BRASIL, BAHIA, Ilhéus, 16.IX.1987, L.A.M. Silva 2208 (RB277810).

Leguminosae/Papilionoideae

Machaerium aculeatum (Vell.) Stellfeld

$$
\text { (Pr. 6, Figs. } 85 \text { - 87) }
$$

Grãos de pólen de tamanho pequeno, isopolares, subprolatos, âmbito subcircular a triangular, 3-zonocolporados, cólporos longos e estreitos, com extremidades afiladas e operculados, endoabertura lalongada, retangular; exina de 1,10-1,25 $\mu \mathrm{m}$ de espessura, sexina microrreticulada, muito mais espessa do que a nexina.

Material examinado: BRASIL, RIO DE JANEIRO, Cachoeira de Macacú, 23.I.2001, F.B. Pereira 19/66 (RB360538).

\section{Pterocarpus rohrii Vahl}

$$
\text { (Pr. 6, Figs. } 88 \text { - 91) }
$$

Grãos de pólen de tamanho pequeno, isopolares, subprolatos, âmbito circular, 3-zono-colporados, cólporos longos e estreitos, com extremidades afiladas e margem estreita, endoabertura circular a ligeiramente lolongada; exina de 1,50-1,80 $\mu \mathrm{m}$ de espessura, sexina microrreticulada, com lumens menores nas margens dos colpos, com o dobro da espessura da nexina.

Material examinado: BRASIL, RIO DE JANEIRO, REBIO do Tinguá, 02.XI.2002, S.J. Silva Neto 1718, C. Callado \& W. da Silva (RB423368).

\section{Swartzia myrtifolia J.E. Smith (Pr. 7, Figs. 92 - 95)}

Grãos de pólen de tamanho pequeno a médio, isopolares, prolatos, âmbito subcircular, 3-zono-colporados, cólporos longos e estreitos, com extremidades afiladas e elementos da sexina, com margem saliente na região equatorial, endoabertura lalongada, retangular; exina de 2,00-2,50 $\mu \mathrm{m}$ de espessura, sexina microrreticulada, muito mais espessa do que a nexina.

Material examinado: BRASIL, RIO DE JANEIRO, Rio Claro, s.d., F.B. Pereira 04/134 (RB366207).

\section{Moraceae}

Sorocea bonplandii (Baillon) Burger, Lanj. \& Boer (Pr. 7, Figs. 96 - 99)

Grãos de pólen de tamanho pequeno, isopolares, oblato-esferoidais a prolato-esferoidais, âmbito subcircular, 2-(-3)-zonoporados, raríssimas vezes 4-5-porados, providos de áspide, operculados; exina de 0,70-0,85 $\mu \mathrm{m}$ de espessura, sexina granulada, um pouco mais espessa do que a nexina. Material examinado: BRASIL, RIO DE JANEIRO, Nova Friburgo, 18.VIII.1989, M. Peron et al. 851 (RB294382).

Myrsinaceae

Myrsine umbellata Mart.

(Pr. 7, Figs. 100 - 103)

Grãos de pólen de tamanho pequeno a médio, isopolares, prolato-esferoidais, âmbito quadrangular, circular-lobado ou subtriangular a triangular, 4-zono-colpados, raríssimas vezes 3-5-colpados, colpos curtos e estreitos, com margem; exina de $0,95-1,00 \mu \mathrm{m}$ de espessura, sexina rugulada, com o dobro da espessura da nexina.

Material examinado: BRASIL. Minas Gerais: Diamantina, 06.VI.1985, F. Barros 1131 (SP294441).

\section{Myrtaceae \\ Campomanesia eugenioides (Cambess.) D. Legrand} (Pr. 7, Figs. 104 - 106)

Grãos de pólen de tamanho pequeno a médio, isopolares, oblatos, âmbito triangular, 3-zono-colporados, sincolpados, cólporos estreitos, conservando sempre a mesma largura, endoabertura lalongada, com extremidades afiladas e com amplo fastígio; exina de 0,60-1,00 $\mu \mathrm{m}$ de espessura, sexina escabrada, um pouco mais espessa do que a nexina.

Material examinado: BRASIL, RIO DE JANEIRO, Pedra de Guaratiba, 06.VI.1992, L.F.T. Menezes $s / n^{\circ}$ (RB297161).

\section{Eugenia maroviana $\mathrm{O}$. Berg \\ (Pr. 8, Figs. 107 - 108)}

Grãos de pólen de tamanho pequeno, isopolares, suboblatos, âmbito triangular, 3-zono-colporados, sincolpados, cólporos estreitos, conservando sempre a mesma largura, porém alargando-se sobre as endoaberturas, endoabertura lalongada, com extremidades afiladas e com pequeno fastígio; exina de 0,60-1,00 $\mu \mathrm{m}$ de espessura, sexina escabrada, com o dobro da espessura da nexina. 

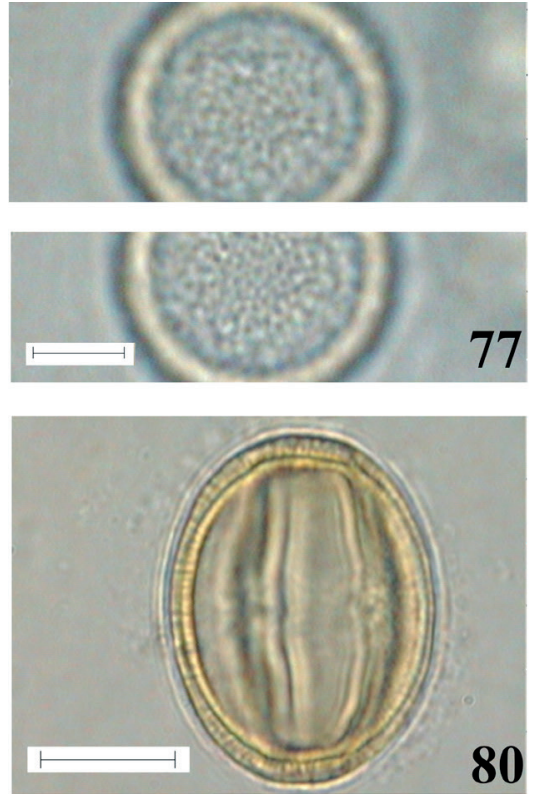

80
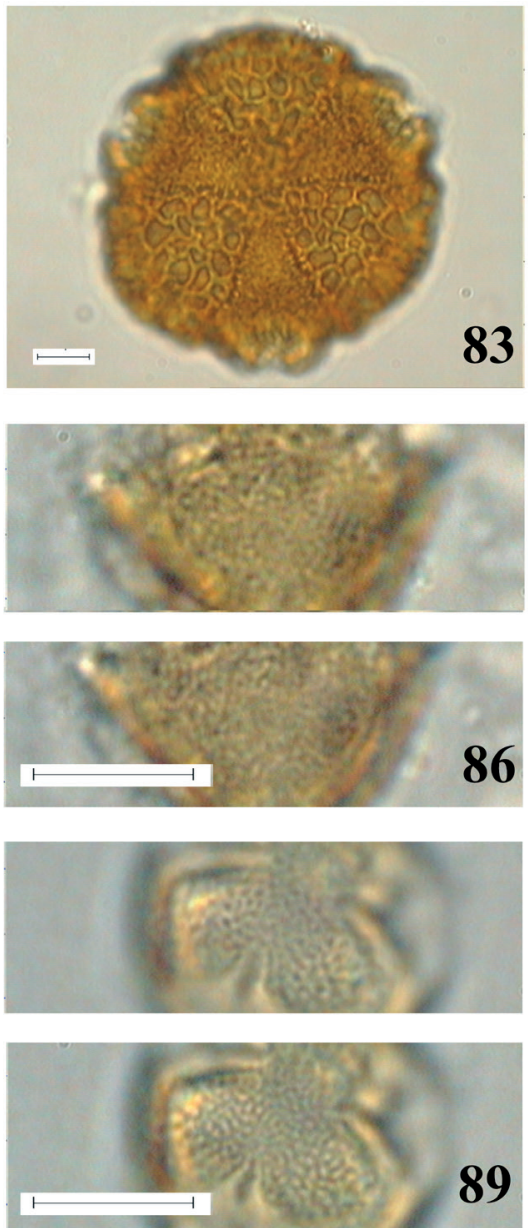
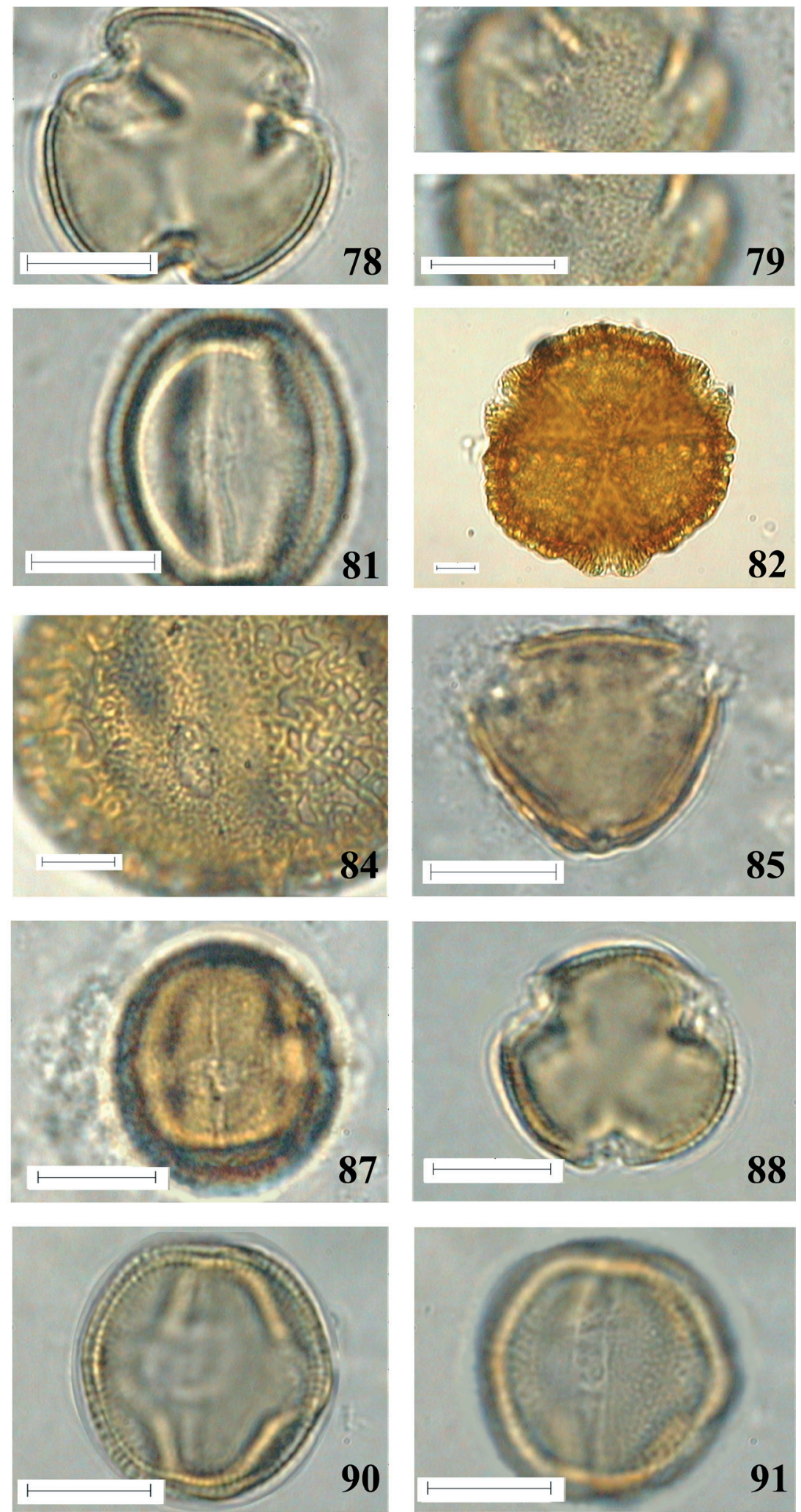

Figs. 77-91. 77. Ocotea divaricata. Ornamentação da superfície, primeiro e segundo focos de visualização. 78-81. Cariniana ianeirensis. 78. Vista polar; 79. Ornamentação da superfície, primeiro e segundo focos de visualização; 80. Vista equatorial; 81. Detalhe da abertura. 82-84. Caesalpinia echinata. 82. Vista polar; 83. Vista polar, detalhe da ornamentação da superfície; 84. Vista equatorial, detalhe da abertura. 85-87. Machaerium aculeatum. 85. Vista polar; 86. Ornamentação da superfície, primeiro e segundo focos de visualização; 87. Vista equatorial, detalhe da abertura. 88-91. Pterocarpus rohrii. 88. Vista polar; 89. Ornamentação da superfície, primeiro e segundo focos de visualização; 90. Vista equatorial; 91. Detalhe da abertura. Barras: Fig. $\mathbf{7 7}=$ $5 \mu \mathrm{m}$; Figs. 78-91 $=10 \mu \mathrm{m}$. 

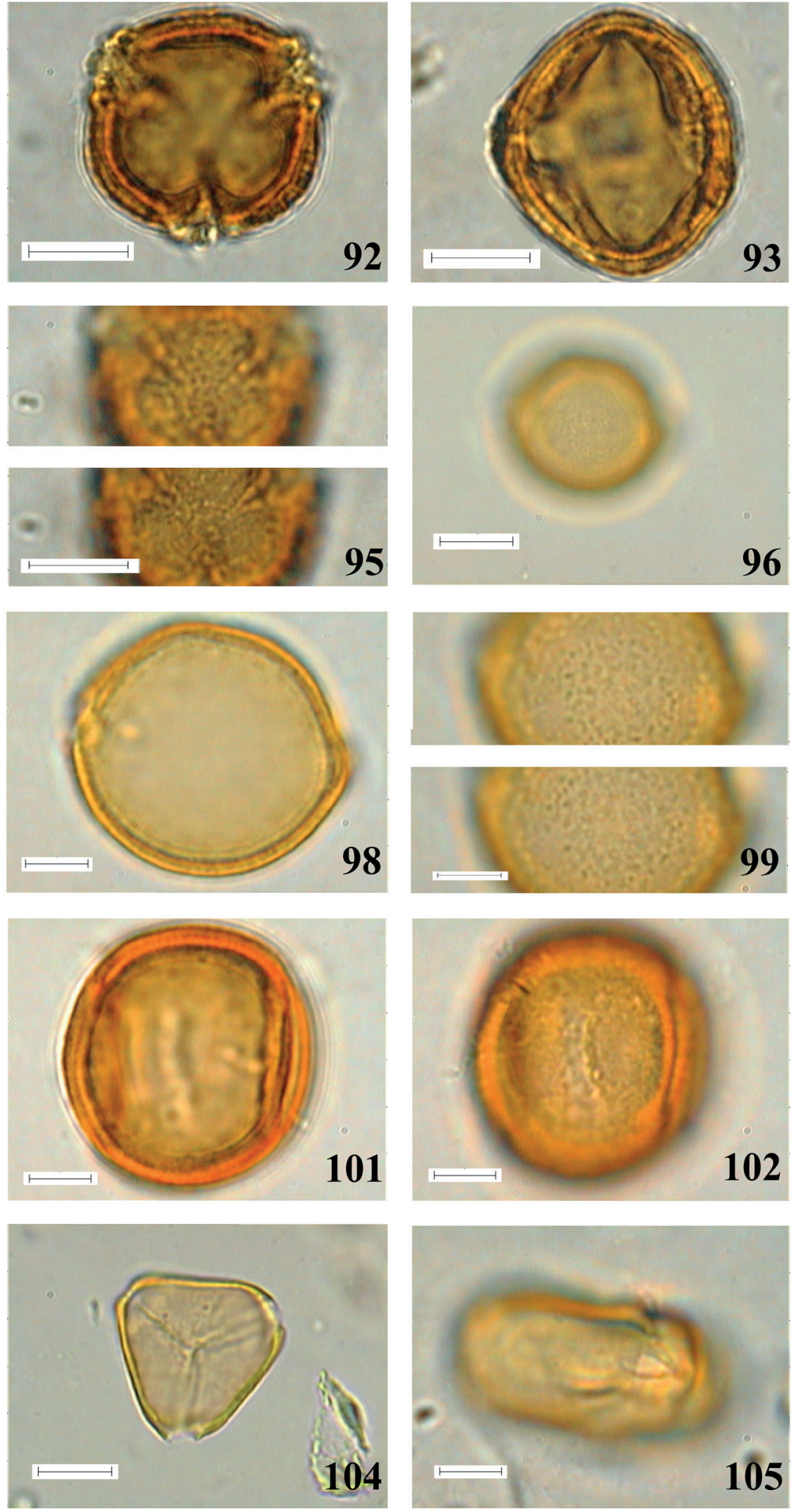
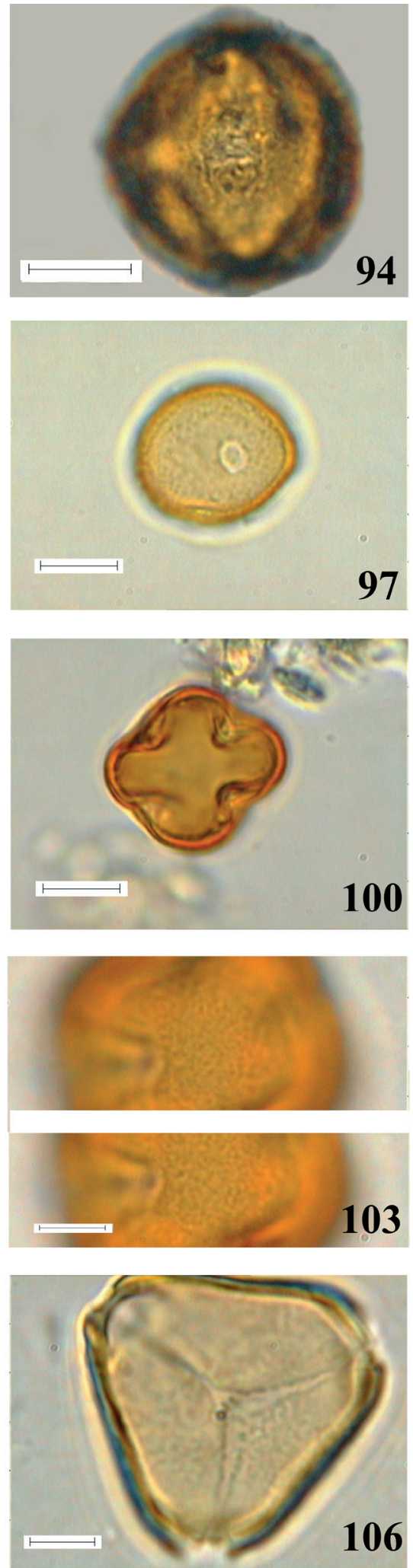

Figs. 92-106. 92-95. Swartzia myrtifolia. 92. Vista polar; 93. Vista equatorial; 94. Detalhe da abertura; 95. Ornamentação da superfície, primeiro e segundo focos de visualização. 96-99. Sorocea bonplandii. 96. Vista equatorial; 97. Detalhe da abertura; 98. Vista equatorial, corte óptico da exina; 99. Ornamentação da superfície, primeiro e segundo focos de visualização. 100-103. Myrsine umbellata. 100. Vista polar; 101. Vista equatorial; 102. Detalhe da abertura; 103. Ornamentação da superfície, primeiro e segundo focos de visualização. 104-106. Campomanesia eugenioides. 104. Vista polar; 105. Vista equatorial; 106. Detalhe do apocolpo. Barras: Figs. 98, 99, 101, 102, 103, 105, $106=5 \mu \mathrm{m}$; Figs. 92-97, 100, 104 =10 $\mu \mathrm{m}$. 
Material examinado: BRASIL, RIO DE JANEIRO, Búzios, 27.I.1997, A. Lobão, P.R. Farrag \& F.C.P. Tatagiba 204 (RB369068).

Syzygium cumini (L.) Skeels (Pr. 8, Figs. 109 - 110)

Grãos de pólen de tamanho pequeno, isopolares, oblatos, âmbito triangular, 3-4-zono-colporados, sincolpados, amplamente sincolpados, endoabertura lalongada, com extremidades afiladas e com amplo fastígio; exina de 0,50$1,00 \mu \mathrm{m}$ de espessura, sexina escabrada, tão espessa quanto a nexina.

Material examinado: BRASIL, SÃO PAULO, São Paulo, 08.XI.1946, W. Hoehne 2313 (RB435433).

Nyctaginaceae

Guapira hirsuta (Choisy) Lundell

(Pr. 8, Figs. 111 - 114)

Grãos de pólen de tamanho médio, isopolares, oblato esferoidais à prolato esferoidais, âmbito circular, 3-zonocolpados, colpos longos e estreitos, com extremidades arredondadas e membrana com elementos isolados da sexina; exina de 1,00-1,50 $\mu \mathrm{m}$ de espessura, sexina espiculada-granulada, com o dobro da espessura da nexina. Material examinado: BRASIL, RIO DE JANEIRO, Pedra de Guaratiba, 23.XI.2001, G.L. Peixoto \& M.V.O. Muniz 62 (RB374031).

\section{Guapira opposita (Vell.) Reitz}

(Pr. 8, Figs. 115 - 118)

Grãos de pólen de tamanho médio, isopolares, oblato esferoidais, âmbito circular, 3-zono-colpados, colpos longos e estreitos, com extremidades arredondadas e membrana com elementos isolados da sexina; exina de 1,60-1,75 $\mu \mathrm{m}$ de espessura, sexina espiculada-granulada, com o dobro da espessura da nexina.

Material examinado: BRASIL, SÃO PAULO, Cananéia, 29.XI.1988, C. Farney et al. 2209 (SP225997).

Ochnaceae

Ouratea stipulata (Vell.) Sastre

(Pr. 8, Figs. 119 - 121, Pr. 9, Figs. 122)

Grãos de pólen de tamanho pequeno, isopolares, oblato esferoidais, âmbito subcircular, 3-zono-colporados, cólporos curtos e estreitos, com extremidades afiladas e margem estreita, endoabertura lalongada, retangular; exina de $0,90-1,00 \mu \mathrm{m}$ de espessura, sexina granulada, um pouco mais espessa do que a nexina.

Material examinado: BRASIL, RIO DE JANEIRO, Parque Municipal Ecológico da Prainha, Grumari, 19.III.2004, M.C. Souza $s / n^{\circ}$ (RB429324).
Phytolaccaceae

Seguieria floribunda Benth (nome válido Seguieria americana $\mathrm{L}$.)

(Pr. 9, Figs. 123 - 126)

Grãos de pólen de tamanho pequeno a médio, isopolares, subprolatos), âmbito circular, 3-zono-colpados, colpos longos e estreitos, com extremidades arredondadas e elementos isolados da sexina; exina de $0,80-1,10 \mu \mathrm{m}$ de espessura, sexina granulada, com o dobro da espessura da nexina.

Material examinado: BRASIL, RIO DE JANEIRO, Reserva Ecológica Estadual de Jacarepiá, Saquarema, 29.XI.1993, R. Paixão \& A.L. Almeida 261 (RB309644).

Rubiaceae

Coutarea hexandra (Jack.) K. Schum (Pr. 9, Figs. 127 - 130)

Grãos de pólen de tamanho médio, isopolares, oblato esferoidais, âmbito subcircular, 3-zono-colpados, colpos

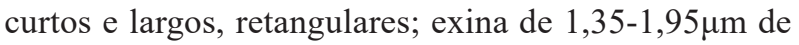
espessura (sem contar os espículos), sexina espiculada (espículo com cerca de $0,48 \mu \mathrm{m}$ ), muito mais espessa do que a nexina.

Material examinado: BRASIL, RIO DE JANEIRO, Ilha da Cotia, ParatyMirim, 08.I.1989, G. Martineli, S. Mayo \& N. Menezes 13295 (RB279466).

\section{Psychotria carthagenensis Jacq} (Pr. 9, Figs. 131- 133)

Grãos de pólen de tamanho médio, isopolares, oblato esferoidais, âmbito subcircular, 3-zono-colpados, colpos curtos e largos, com extremidades arredondadas; exina de $1,45-2,00 \mu \mathrm{m}$ de espessura, sexina reticulada, heterobrocada, muito mais espessa do que a nexina.

Material examinado: BRASIL, RIO DE JANEIRO, Ilha da Gipóia, Angra dos Reis, 02.XII.2001, H.C. Lima, R.R. Oliveira, J.E. Meirelles \& F.D. Irias 5961 (RB367743).

Rutaceae

Pilocarpus spicatus A. St.-Hil

(Pr. 9, Figs. 134 - 136)

Grãos de pólen de tamanho pequeno a médio, isopolares, prolatos, âmbito subcircular, lobado, 3-zonocolporados, cólporos longos e estreitos, com extremidades afiladas, endoabertura lalongada, com extremidades afiladas; exina de $1,15-1,25 \mu \mathrm{m}$ de espessura, sexina microrreticulada, ligeiramente estriada, com o dobro da espessura da nexina.

Material examinado: BRASIL, RIO DE JANEIRO, Restinga da Marambaia, 29.V.2004, H.M. Dias, A. Solorzano \& L. Scumm 99 (RB415717). 

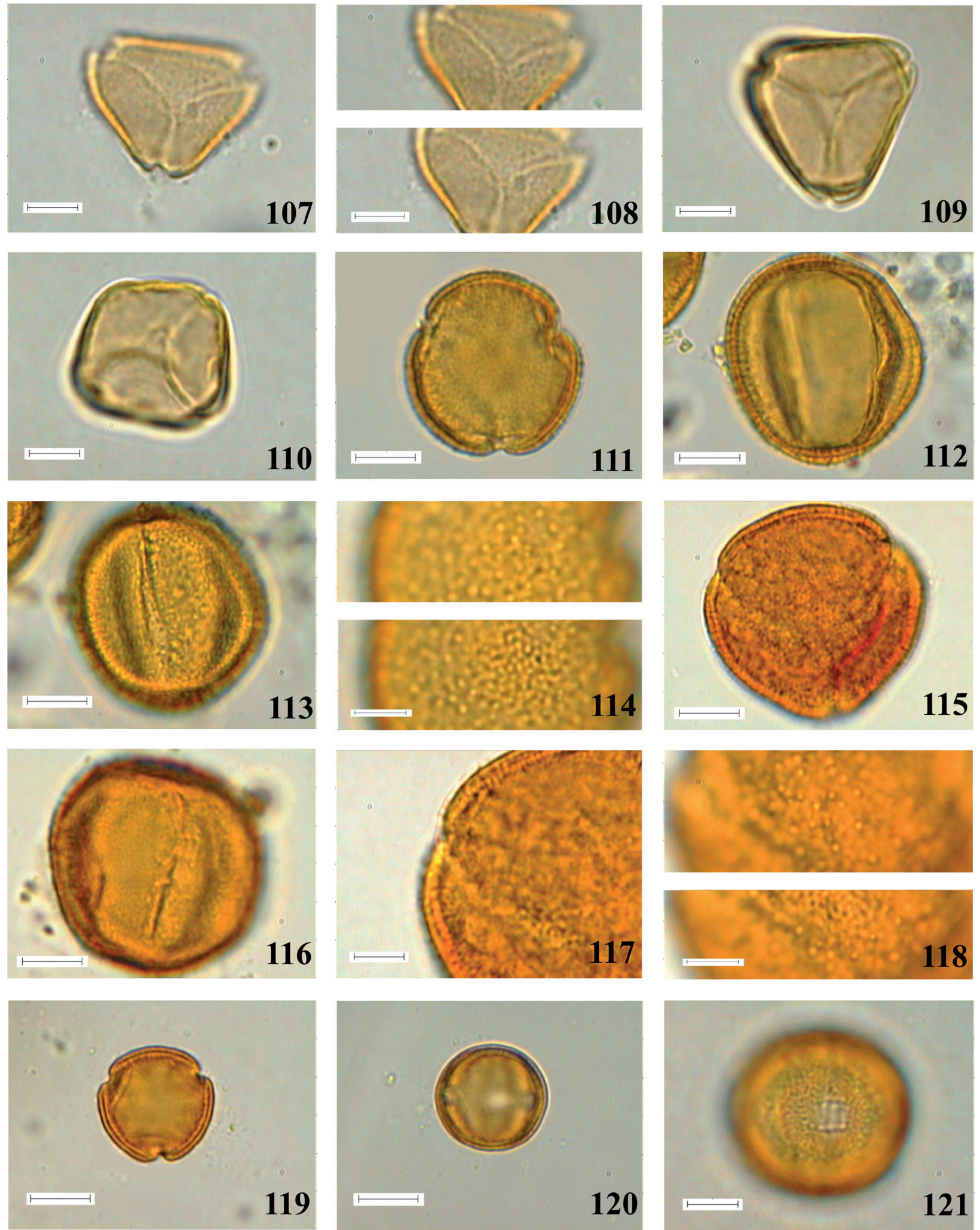

Figs. 107-121.107-108. Eugenia maroviana. 107. Vista polar, detalhe do apocolpo; 108. Ornamentação da superfície, primeiro e segundo focos de visualização. 109110. Syzygium cumini. 109. Vista polar, grão de pólen 3-sincolporado; 110. Vista polar, grão de pólen 4-sincolporado. 111-114. Guapira hirsuta. 111. Vista polar; 112. Vista equatorial; 113. Detalhe da abertura; 114. Ornamentação da superficie, primeiro e segundo focos de visualização. 115- 118. Guapira opposita. 115. Vista polar; 116. Vista equatorial; 117. Detalhe da abertura; 118. Ornamentação da superfície, primeiro e segundo focos de visualização. 119-121. Ouratea stipulata. 119. Vista polar; 120. Vista equatorial; 121. Detalhe da abertura. Barras: Figs. 107, 108, 109, 110, 114, 117, 118, $121=5 \mu \mathrm{m}$; Figs. 111, 112, 113, 115, 116, 119, 120 = 10 $\mu \mathrm{m}$. 

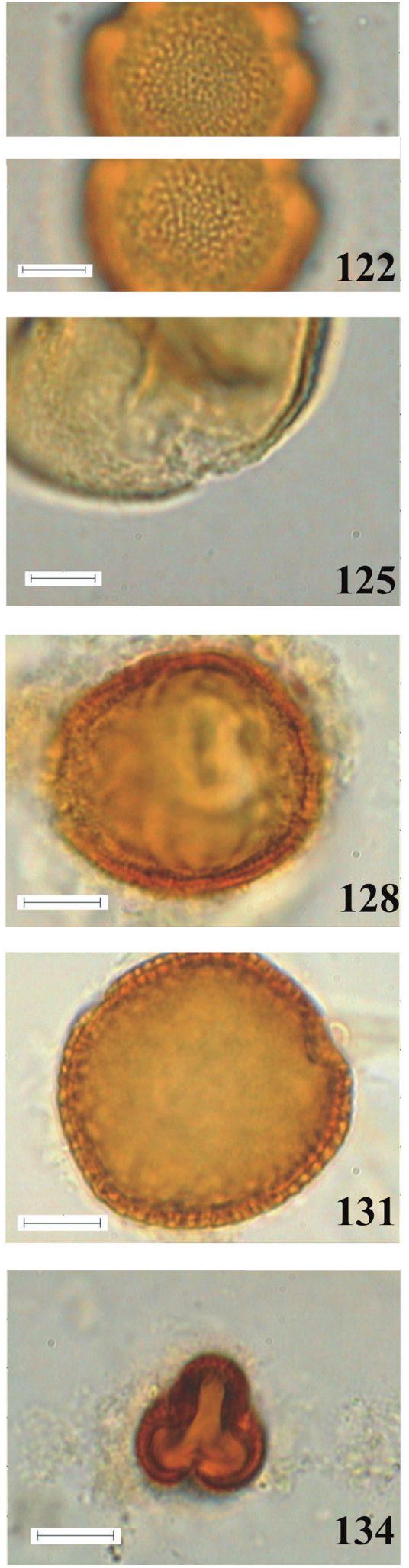
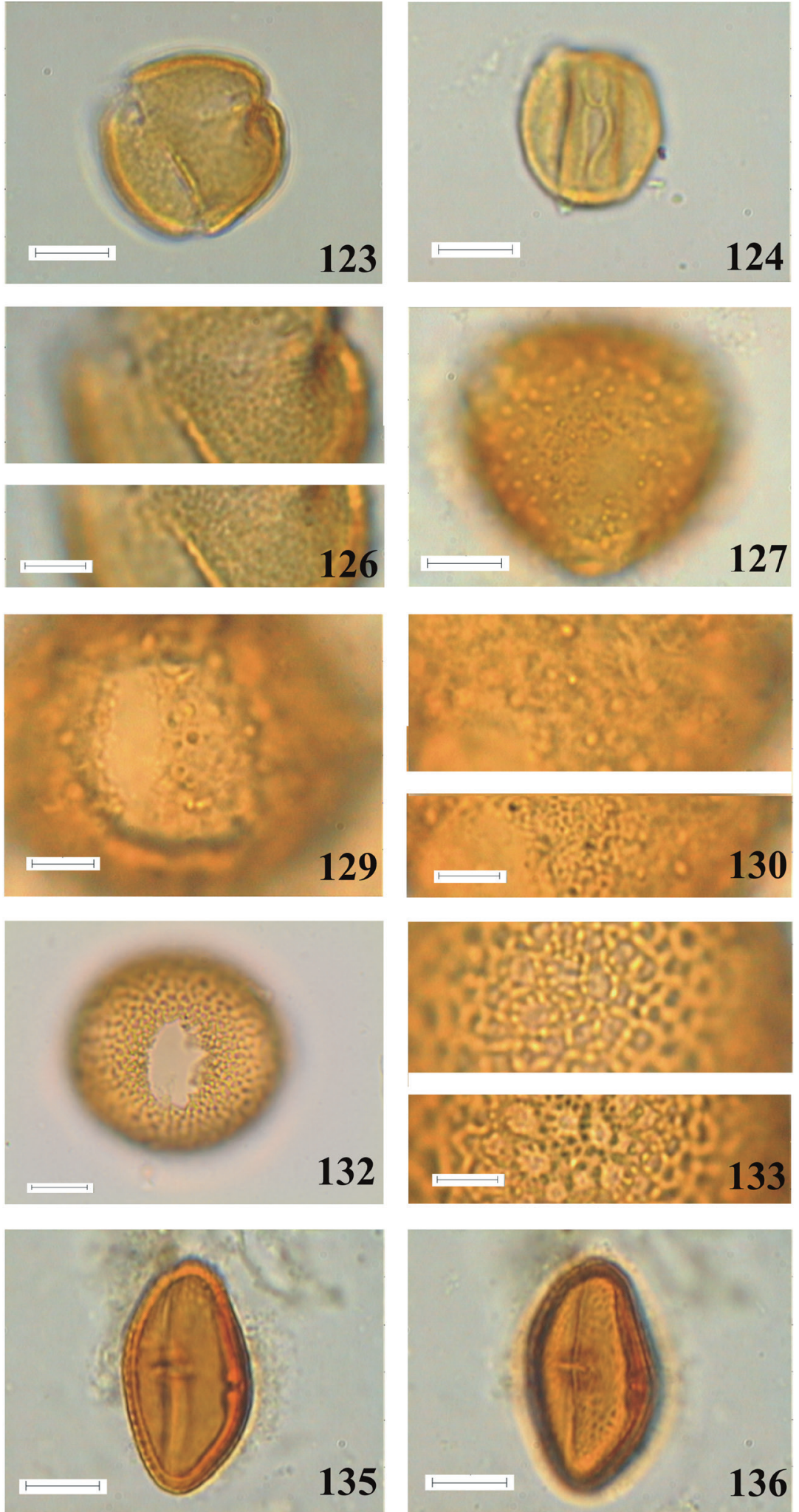

Figs. 122-136. 122. Ourate astipulata. Ornamentação da superfície, primeiro e segundo focos de visualização. 123-126. Seguieria floribunda. 123. Vista polar; 124. Vista equatorial; 125. Detalhe da abertura; 126. Ornamentação da superfície, primeiro e segundo focos de visualização. 127-130. Coutarea hexandra. 127. Vista polar; 128. Vista equatorial; 129. Detalhe da abertura; 130. Ornamentação da superfície, primeiro, segundo e terceiro focos de visualização. 131-133. Psychotria carthagenensis. 131. Vista polar; 132. Vista equatorial, detalhe do colpo; 133. Ornamentação da superfície, primeiro e segundo focos de visualização. 134-136. Pilocarpus spicatus. 134. Vista polar; 135. Vista equatorial; 136. Detalhe da abertura. Barras: Figs. 122, 125, 126, 129, 130, $133=5 \mu \mathrm{m}$; Figs. 123, 124, 127, 128, 131, 132, 134-136 $=10 \mu \mathrm{m}$. 


\section{AGRADECIMENTOS}

Somos gratos ao Instituto Estadual do Ambiente (INEA) na pessoa da Me. Cristiana Pompeo do Amaral Mendes pelo convite para realizarmos pesquisa com Palinologia no Parque Estadual da Pedra Branca e ao Prof. Dr. Edson Farias Mello, Departamento de Geologia, Universidade Federal do Rio de Janeiro, por permitir realizar as investigações palinológicas como complemento às suas atividades de pesquisa no referido local. À Fundação de Amparo à Pesquisa do Estado do Rio de Janeiro Carlos Chagas Filho pelo auxílio financeiro (FAPERJ, número do processo E-26/101.568/2010-13). A primeira e terceira autoras são gratas ao Conselho Nacional de Desenvolvimento Científico e Tecnológico (CNPq) pelas bolsas de "Produtividade em Pesquisa" (processos números 302766/2016-2 e 301992/2017-7).

\section{REFERÊNCIAS}

APG. 2009. Angiosperm phylogeny group. An update of the Angiosperm Phylogeny Group classification of the orders and families of flowering plants. Journal of the Linnean Society 161: 105-121.

Barth, M.O. \& Melhem, T.S. 1988. Glossário Ilustrado de Palinologia. Universidade Estadual de Campinas, Campinas. $77 \mathrm{p}$.

Cronquist, A. 1988. The evolution and classification of flowering plants. The New York Botanical Garden, New York. 555 p.

Erdtman, G. 1960. The acetolysis method. A revised description. Svensk Botanisk Tidskrift 54:561-564.

Flora do Brasil 2020 em construção. Jardim Botânico do Rio de Janeiro. Disponível em: http://floradobrasil.jbrj.gov.br/. Acessado em 14.10.2018.

Freire, J.M. 2010. Fitossociologia e estrutura do componente arbóreo de um remanescente de floresta urbana no maciço da Pedra Branca, Rio de Janeiro. Tese, 129 f., Universidade Federal Rural do Rio de Janeiro, Rio de Janeiro.
Google Maps. Serra da Capoeira Grande. 2016. Disponível em: https:// www.google.com.br/maps/place/Serra+da+Capoeira+Grande/@$22.9778633,-43.6196724,8082 \mathrm{~m} / \mathrm{data}=! 3 \mathrm{~m} 1 ! 1 \mathrm{e} 3 ! 4 \mathrm{~m} 5 ! 3 \mathrm{~m} 4 ! 1 \mathrm{~s} 0 \times 9 \mathrm{~b}$ efdfd2f86731:0x7ca15fe91114b0c2!8m2!3d-22.98!4d-43.6352778. Acessado em 18.10.2018.

Magalhães-Corrêa, A. 1933. O Sertão Carioca. Revista do Instituto Histórico e Geográfico Brasileiro 167:1-312.

Melhem, T.S. \& Matos, M.E.R. 1972. Variabilidade de forma nos grãos de pólen de Eriopecrassipes Benth. Labiatae. Hoehnea 2:1-10.

Oliveira, R.R. 2005. As marcas do homem na floresta. História ambiental de um trecho de Mata Atlântica. Pontifícia Universidade Católica do Rio de Janeiro, Rio de Janeiro. 230 p.

Pereira, E.S. 2010. Geodiversidade do Parque Estadual da Pedra BrancaRJ: Subsídios para o planejamento Geoturístico. Dissertação, 168 p. Universidade Federal do Rio de Janeiro, Rio de Janeiro.

Peixoto, G.L., Martins, S.V., Silva, A.F. \& Silva, E. 2004. Composição florística do componente arbóreo de um trecho de floresta atlântica na área de proteção ambiental da Serra da Capoeira Grande, Rio de Janeiro, RJ, Brasil. Acta Botanica Brasílica 18:151-160.

Peixoto, G.L., Martins, S.V., Silva, A.F. \& Silva, E. 2005. Estrutura do componente arbóreo de um trecho de Floresta Atlântica na Área de Proteção Ambiental da Serra da Capoeira Grande, Rio de Janeiro, RJ, Brasil. Acta Botanica Brasílica 19:539-547.

Punt, W., Hoen, P.P., Blackmore, S., Nilsson, S. \& Le Thomas, A. 2007. Glossary of pollen and spore terminology. Review of Palaeobotany and Palynology 143: 1-81

Salgado-Labouriau, M.L. 1973. Contribuição à Palinologia dos Cerrados. Academia Brasileira de Ciências, Rio de Janeiro. 285 p.

Salgado-Labouriau, M.L., Vanzolini, P.E. \& Melhem, T.S. 1965. Variation of polar axes and equatorial diameters in pollen grains of the two species of Cassia. Grana Palynologica 6: 166-176.

Santos, F.V., Solórzano, A., Guedes-Bruni, R.R., Oliveira, R.R. 2006. Composição do estrato arbóreo de um paleoterritório de carvoeiros no Maciço da Pedra Branca, RJ. Pesquisas Botânica 57:181-192.

Solórzano, A. 2006. Composição florística, estrutura e História Ambiental em áreas de Mata Atlântica no Parque Estadual da Pedra Branca, RJ. 141 p. Dissertação, 141 f. Escola Nacional de Botânica Tropical, Instituto de Pesquisas Jardim Botânico do Rio de Janeiro, Rio de Janeiro. 